\section{Structural heterogeneity and permeability in faulted eolian sandstone: Implications for subsurface modeling of faults}

\author{
Zoe K. Shipton, James P. Evans, Kim R. Robeson, \\ Craig B. Forster, and Stephen Snelgrove
}

\begin{abstract}
We determined the structure and permeability variations of a $4 \mathrm{~km}-$ long normal fault by integrating surface mapping with data from five boreholes drilled through the fault (borehole to tens of meters scale). The Big Hole fault outcrops in the Jurassic Navajo Sandstone, central Utah. A total of $363.2 \mathrm{~m}$ of oriented drill core was recovered at two sites where fault displacement is 8 and $3-5 \mathrm{~m}$. The main fault core is a narrow zone of intensely comminuted grains that is a maximum of $30 \mathrm{~cm}$ thick and is composed of lowporosity amalgamated deformation bands that have slip surfaces on one or both sides. Probe permeameter measurements showed a permeability decline from greater than 2000 to less than $0.1 \mathrm{md}$ as the fault is approached. Whole-core analyses showed that fault core permeability is less than $1 \mathrm{md}$ and individual deformation band permeability is about $1 \mathrm{md}$. Using these data, we calculated the bulk permeability of the fault zone. Calculated transverse permeability over length scales of $5-10 \mathrm{~m}$ is $30-40 \mathrm{md}$, approximately $1-$ $4 \%$ the value of the host rock. An inverse power mean calculation (representing a fault array with complex geometry) yielded total fault-zone permeabilities of 7-57 md. The bulk fault-zone permeability is most sensitive to variations in fault core thickness, which exhibits the greatest variability of the fault components.
\end{abstract}

\section{INTRODUCTION}

The permeability of fault zones is a function of the fault-zone architecture and the intrinsic properties of the fault-related rocks (Caine et al., 1996; Fisher and Knipe, 1998; Gibson, 1998). Fault zones can be barriers to fluid flow, conduits, or a mixture of barriers and conduits. The fluid flow behavior of a fault zone varies as a function of fault permeability, geometry, and the location of the

Copyright (C2002. The American Association of Petroleum Geologists. All rights reserved.

Manuscript received September 7, 2000; revised manuscript received August 16, 2001; final acceptance January 17, 2002.

\section{AUTHORS}

ZoE K. SHIPTON Department of Geology, Utah State University, Logan, Utah, 843224505; current address: Department of Geology, Trinity College, Dublin 2, Ireland; shiptonz@tcd.ie

Zoe Shipton received her B.S. degree from the University of Leeds and her Ph.D. from the University of Edinburgh, United Kingdom. She recently completed a postdoctoral fellowship at Utah State University. Her research emphasizes three-dimensional fault growth and fluid flow through time, using integrated surface mapping and drill core data. She is currently a lecturer in structural geology at Trinity College, Dublin.

James P. Evans $\sim$ Department of Geology, Utah State University, Logan, Utah, 843224505; jpevans@cc.usu.edu

James Evans received B.S. degrees in geology and engineering from the University of Michigan and an M.S. degree and Ph.D. from Texas A\&M University. He is a professor at Utah State University and chief editor of the Journal of Structural Geology. His research examines rock deformation in the brittle and semibrittle fields, relationships between fluid flow and deformation, and deformation mechanisms of seismogenic faults.

KIM R. RoBeson $\sim$ Deceased.

After working as a technical draftsman in the aerospace industry, Kim Robeson received his B.S. degree in geology from California State University at San Bernadino and his master's degree on fault development from Utah State University. Kim died in November 1998.

CRAig B. Forster $\sim$ Department of Geology and Geophysics, University of Utah, Salt Lake City, Utah, 84112-1183; cforster@mines.utah.edu

Craig Forster received his B.S. degree from the University of British Columbia, an M.Sc. degree from the University of Waterloo, and his Ph.D. at the University of British Colombia. He is a research professor at the University of Utah and Utah State University. His research examines permeability heterogeneity in flow simulators, the hydraulic properties of faults, and water resources and environmental issues. 
StePHEN SNelgrove $\sim$ Department of Geology and Geophysics, University of Utah,

Salt Lake City, Utah, 84112-1183;

ssnelgro@mines.utah.edu

Stephen Snelgrove received a B.S. degree in geophysics, an M.S. degree in geological engineering from the University of Utah, and is currently a Ph.D. student in civil engineering at the University of Utah. He worked for Phillips Petroleum from 1978 to 1986 . His research interests are in the construction of geologically sound subsurface models and flow simulations.

\section{ACKNOWLEDGEMENTS}

Funding for this work was provided by the OBES-Department of Energy grants DE-FG0300ER15042 and DE-FG03-95ER14526 and by the Big Hole drilling sponsors: ARCO and ARCO Alaska, Enterprise Oil, Exxon, the Japanese National Oil Company, Mobil, Shell, Schlumberger-Doll Research, and Statoil. Reviews by Marco Antonellini, Andrew Hurst, and John Lorenz improved the article. We dedicate this article to the memory of Kim Robeson. fault within the local/regional hydrologic setting. The response of fluid flow systems to a fault zone is controlled by the relative permeability values of different components in the fault zone, the interconnectedness of low-permeability fault-zone components, and the shape and dimensions of the resulting high-permeability compartments (cf. Manzocchi et al., 1999). Ideally, a fault zone should be examined in three dimensions to understand fully the fault-zone architecture and permeability structure.

Increasing interest in production from fault-compartmentalized reservoirs (e.g., Gibson, 1994; Welbon et al., 1997; Fisher and Knipe, 1998; Hurlow, 1998; Ottesen Ellevset et al., 1998) and in drilling through fault zones (Santarelli et al., 1992) indicates that borehole-scale studies of fault properties and fault structure are necessary to quantify the in-situ permeability structure of faults. Of particular interest are the properties and extent of subseismic faults, typically those faults that have displacements less than 8-10 $\mathrm{m}$ that cannot easily be resolved using most seismic reflection techniques. Subsurface analyses of fault-related rocks, combined with mapping studies, allow us to develop three-dimensional interpretations of fault structure and properties. Data sets of this quality and breadth are uncommon, because faults are commonly considered a drilling hazard and, therefore, not cored. These analyses can lead to greater insights into fault growth processes and more robust predictive methods of in-situ fault properties.

In this integrated project, we obtained a complete set of drillcore and well-log data through a fault zone. Structural analysis allows us to evaluate the fault-rock hydraulic properties and examine the mesoscopic fault architecture. A series of probe permeameter and whole-core permeability tests demonstrates the variability of permeability within and around the fault zone and allows us to correlate permeability changes with rock character in both drill core and outcrop. This integrated approach leads to an understanding of the hydraulic structure of the fault zone in three dimensions and, hence, to a better understanding of the effect faults may have on flow in reservoirs.

\section{GEOLOGIC SETTING}

The Big Hole fault is the southernmost fault in the Chimney Rock fault array in the northern San Rafael Swell, Utah (Figure 1). These mutually crosscutting northwest- and northeast-striking dip-slip normal faults accommodate north-south extension (Krantz, 1988). Timing constraints on the age of faulting are poor. The San Rafael Swell is a broad east-vergent monoclinal flexure (Gilluly, 1929), which is the result of broad arching of Precambrian through early Tertiary rocks. The San Rafael Swell began to form at about $75 \mathrm{Ma}$, and deformation ceased at about $58 \mathrm{Ma}$ (Fouch et al., 1983; Lawton, 1986). Extension parallel to the fold axis, perhaps in regions of maximum plunge, may be the cause of the faulting (Shipton, 1999). Thus, the Chimney Rock faults are probably Late 


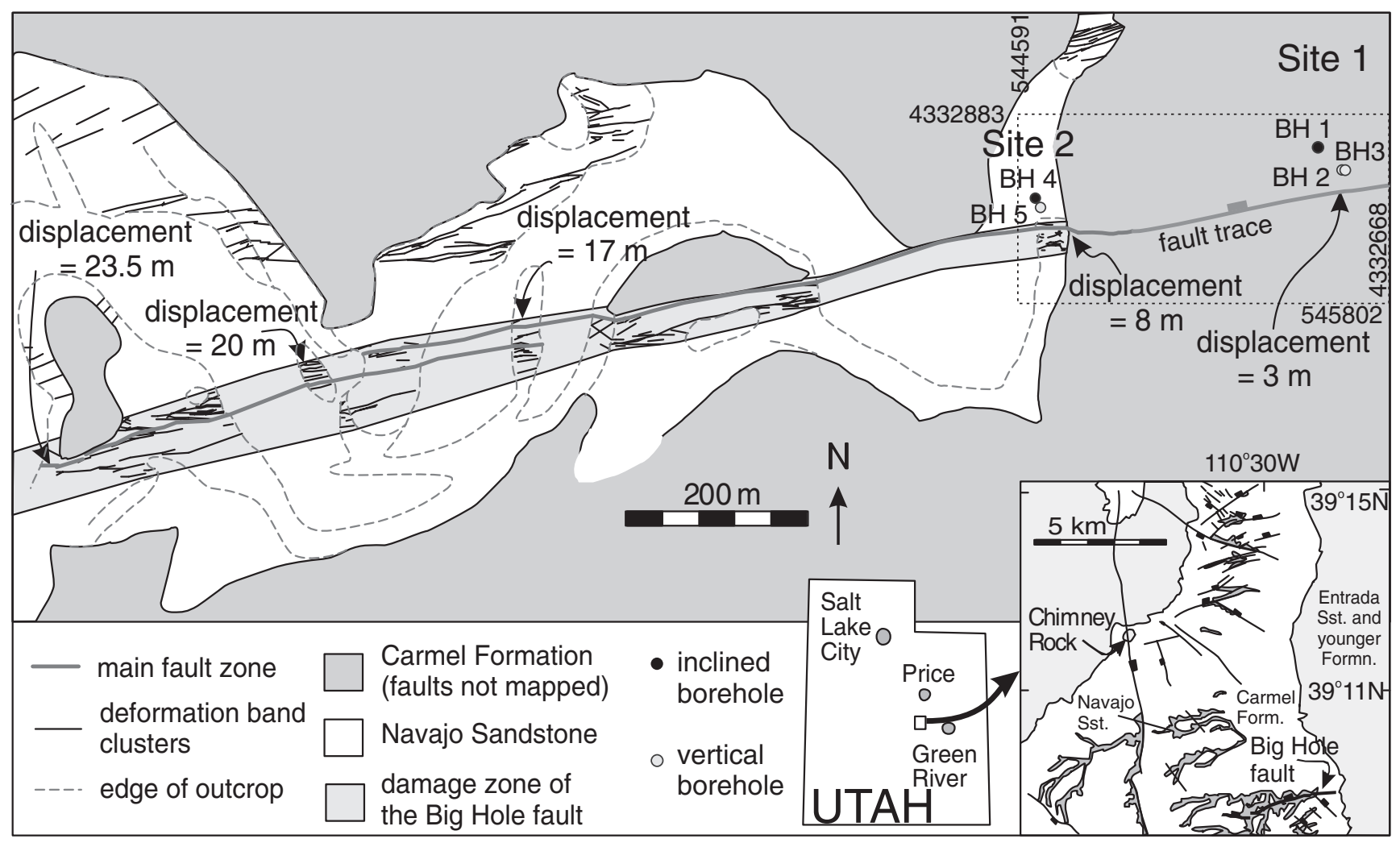

Figure 1. Geologic map of the Big Hole fault (modified from Shipton and Cowie, 2001). The fault is exposed in the bottom of a dry riverbed. The Big Hole fault zone consists of a narrow fault core surrounded by a zone of deformation band clusters (shaded damage zone region). The box highlights the drill site region (UTM zone 12 coordinates at the corners). Drill site 1 is on the eastward projection of the fault surface. Drill site 2 is at the easternmost exposure of the fault. The inset shows the location of the study area in the northern San Rafael Swell, Utah.

Cretaceous-early Tertiary faults. A crude overburden calculation based on a Late Cretaceous age and not accounting for compaction suggests that the Navajo Sandstone experienced a lithostatic load of 40-80 MPa and temperatures of $45-90^{\circ} \mathrm{C}$ during faulting.

The faults cut the 137-151 m-thick Jurassic Navajo Sandstone, a very fine to fine-grained eolian arenite. We informally divide the Navajo Sandstone into three members based on outcrop and core studies of the sedimentology (Thomas et al., 2000): a poorly sorted dune cross-bedded sequence, a middle massive sequence of well-sorted fine sands, and a lower dune cross stratified sequence. The Navajo Sandstone is overlain by the Carmel Formation, a well-bedded, fine-grained limestone. Permeability of the Navajo Sandstone is typically in the 100-1000 md range (Hood and Patterson, 1984). The Navajo Sandstone, in common with other porous rocks, deforms by producing deformation bands (as defined by Aydin, 1978; Aydin and Johnson, 1978). Previous work showed that permeability within deformation bands is reduced by about three orders of magnitude with respect to the host rock (Pittman, 1981; Antonellini and Aydin, 1994). Compartmentalization by deformation band faults has been found to concentrate posttectonic cement and hydrocarbons (Edwards et al., 1993; Antonellini et al., 1999). Deformation band faults can, therefore, represent an important barrier to fluid flow in hydrocarbon reservoir rocks. Conversely, it has been suggested that an increase in permeability is created in the direction parallel to slip because of dilatancy and slip-surface generation (Antonellini and Aydin, 1994).

The Chimney Rock fault array is, therefore, an excellent analog for similar faults in faulted sandstone reservoirs (i.e., Gibson, 1994; Antonellini et al., 1999; Fossen and Hesthammer, 2000). The Chimney Rock faults intersect to create oil field-scale compartments of relatively undeformed host rock in the Navajo Sandstone (Krantz, 1988). Similar faults in the Navajo Sandstone affect local production and injection programs. The nearest producing field in the Navajo Sandstone was the Farnham Dome field, at the north end 
of the San Rafael Swell. This abandoned $\mathrm{CO}_{2}$ field produced 4.76 bcf gas, from an average porosity of $12 \%$. The reservoir is a faulted anticline, with lateral sealing of the Navajo Sandstone by faults (Peterson, 1954; Morgan and Chidsey, 1991). Currently, wastewater from coalbed methane operations is injected into the Navajo Sandstone northwest of the study area (Conway et al., 1997).

The Big Hole fault strikes $N 70^{\circ} \mathrm{E}$, dips $64^{\circ} \mathrm{N}$ at the surface, and has pure dip-slip slickenlines (Figure 1). Throw along the fault is calculated from detailed surveys of the top of the Navajo Sandstone. From a maximum of $29 \mathrm{~m}$, throw decreases approximately linearly toward the easternmost outcrop of the Navajo Sandstone, where the displacement is $8 \mathrm{~m}$ (Shipton and Cowie, 2001). A linear fault-related structure in the Carmel Formation extends at least $500 \mathrm{~m}$ east of this point. Linear extrapolation of slip on the fault from the point of $8 \mathrm{~m}$ of slip suggests the tip line would be as much as $800-1000 \mathrm{~m}$ to the east of the last measurable displacement (Shipton and Cowie, 2001). In this case, slip at drill site 1 is between 3 and $5 \mathrm{~m}$.

Detailed outcrop mapping (Shipton and Cowie, 2001) shows that the Big Hole fault typically consists of a fault core surrounded by a damage zone (cf. Chester and Logan, 1986; Caine et al., 1996). The fault core is a zone of fine-grained, cataclastically deformed rock up to $30 \mathrm{~cm}$ thick (Figure 2a). This is bounded by, or contains, one or more narrow, typically polished or mineralized slip surfaces, along which much of the fault slip is interpreted to have been localized. The fault core commonly exhibits an internal structure of oppositely dipping deformation bands and slip surfaces in cross section (Figure 2b) and in plan view consists of subparallel anastomosing deformation bands (Figure 2c). The damage zone contains anastomosing steep north- and south-dipping clusters of deformation bands. The outer edge of the damage zone is marked by the onset of deformation bands (Figure 1). Very few deformation bands occur outside this zone.

Individual deformation bands form by cataclastic grain crushing (Figure 3a) (Aydin, 1978), which results in a decrease in porosity and permeability (Antonellini and Aydin, 1994). No chemical change is seen between the band and host rock. Individual slip surfaces are expressed in thin section as extremely narrow, opaque, planar structures surrounded by varying thicknesses of fine-grained fault gouge (Figure $3 \mathrm{~b}$ ). The fault core
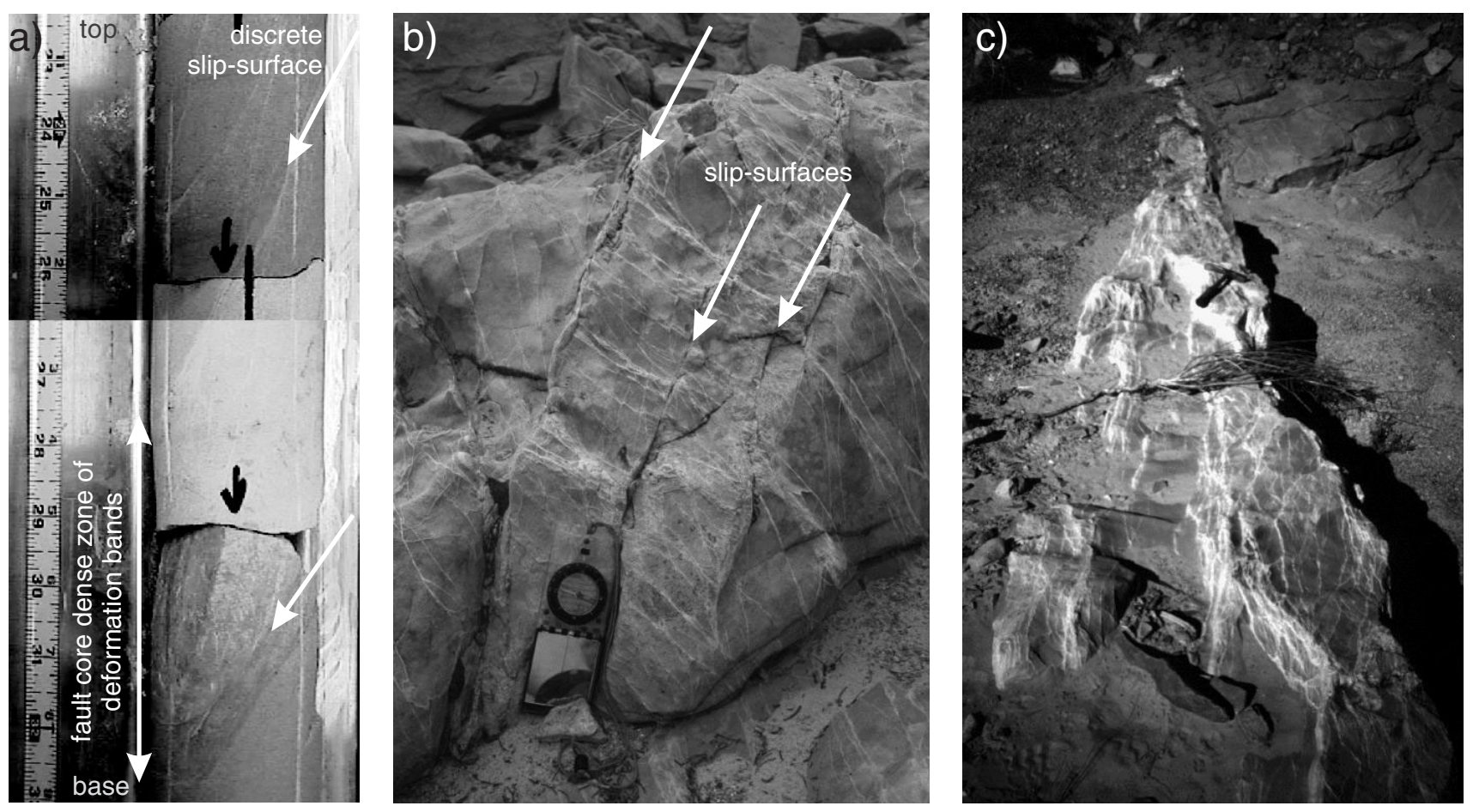

Figure 2. (a) Example of drill core recovered from BH3 where it intersects the fault zone at $59 \mathrm{~m}$ depth. The fault core is expressed as the pale region of amalgamated deformation bands bounded by thin, extremely narrow slip surfaces. (b) An antithetic deformation band cluster in the hanging wall of the Big Hole fault containing synthetic and antithetic deformation bands. Note the compass for scale. (c) Subparallel anastomosing deformation bands within an antithetic deformation band cluster in the hanging wall of the Big Hole fault. Note the hammer for scale. 
(a)

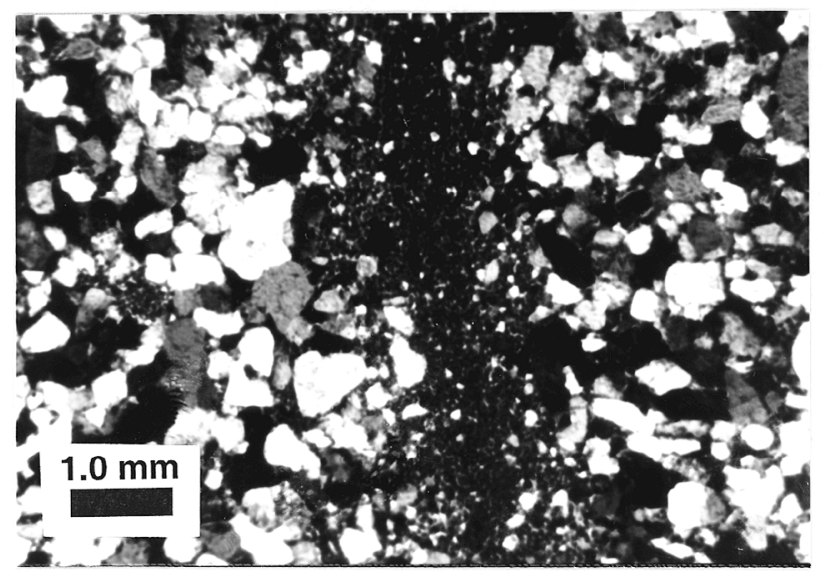

(c)

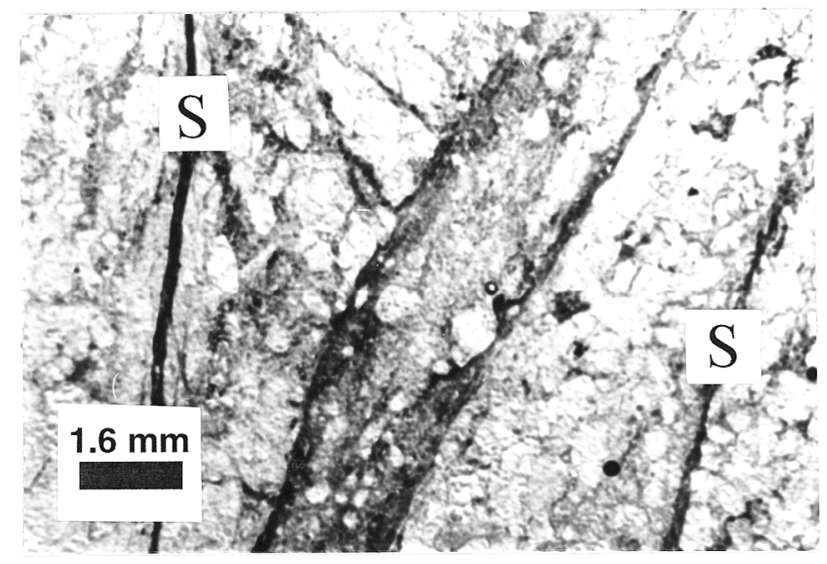

(b)

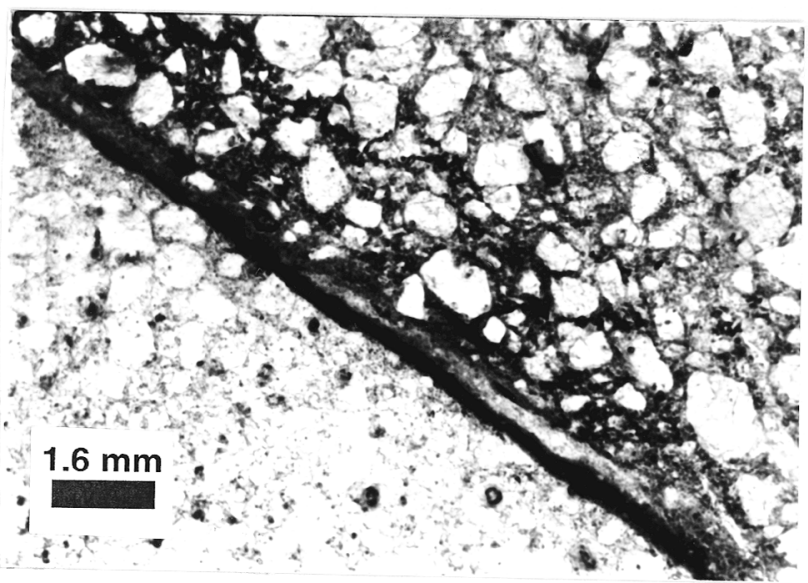

(d)

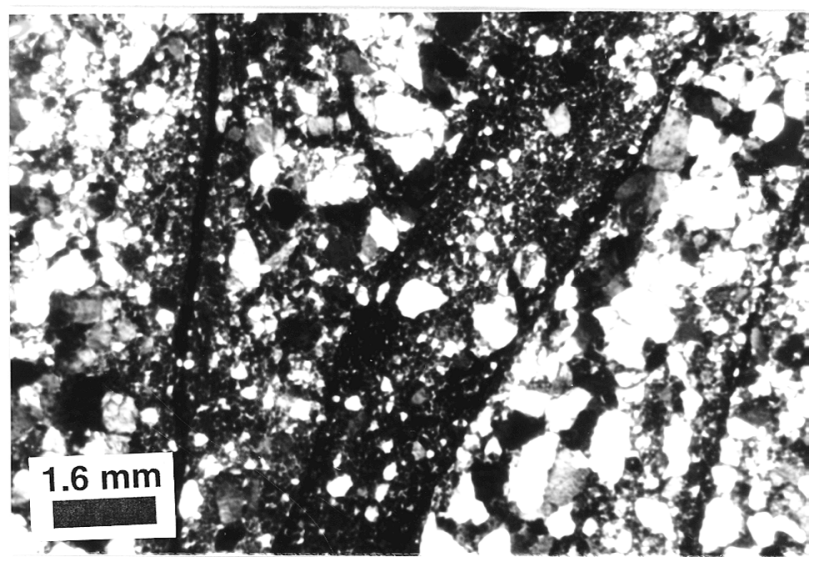

Figure 3. Thin-section photomicrographs showing deformation mechanisms in the different fault components. (a) Single deformation band with brittle grain-size reduction about $1 \mathrm{~mm}$ thick. A slight reduction in grain size can be noted along the boundary of the deformation band. Cross-polarized light photograph. (b) Narrow slip surface (dark) from BH3 separating extremely comminuted quartz grains of the fault core (below) from nearly intact rocks. Plane-polarized light photograph. (c) Plane-polarized light photograph of the fault core at $58.3 \mathrm{~m}$ depth in BH3. The fault core consists here of several well-developed slip surfaces $(\mathrm{S})$, in a zone of highly comminuted fault gouge. (d) Cross-polarized light photograph of the fault core at $58.3 \mathrm{~m}$ depth in $\mathrm{BH}$.

consists of very fine grained fault gouge and pods of relatively undeformed host rock (Figure 3c). The finegrained gouge within the fault zones (Figure 3d) may have porosity less than $1 \%$ (Shipton and Cowie, 2001) and a permeability of at least seven orders of magnitude less than that of the host rock (Antonellini and Aydin, 1994).

\section{DRILLING STRATEGY}

The overall objectives of our work were to (1) conduct a drill core-based structural analysis of the fault zone, (2) determine the geophysical signature and perme- ability structure of a fault zone at and below the limits of seismic resolution, and (3) perform permeability tests at a variety of scales within and across the fault. Defining drilling targets required combining these objectives within the constraints of access, fault displacement, water table level, and budget. Five holes (BH1-5) were drilled into the fault zone at two sites approximately $310 \mathrm{~m}$ apart (Figure 1; Table 1). The boreholes were drilled from the hanging wall and are either vertical or inclined toward the fault (Table 1). Drilling services were provided by Tonto Drilling Services (now Dynatec), Salt Lake City, Utah. All holes were cored using an HQ diameter $(58 \mathrm{~mm})$ core barrel. $\mathrm{BH} 1, \mathrm{BH} 2$, and $\mathrm{BH} 3$ were cored using single-tube 
Table 1. Locations, Orientations, and Depths of the Five Boreholes in the Study Area

\begin{tabular}{|c|c|c|c|c|c|c|c|c|}
\hline & \multicolumn{2}{|c|}{$\begin{array}{l}\text { Depth of } \\
\text { Hole }\end{array}$} & \multirow{2}{*}{$\begin{array}{l}\text { Deviation and } \\
\text { Azimuth }\end{array}$} & \multirow{2}{*}{$\begin{array}{l}\text { Fault Intersection } \\
\text { TVD }(\mathrm{m})\end{array}$} & \multirow{2}{*}{$\begin{array}{c}\text { Depth to } \\
\text { Water Table }(\mathrm{m})\end{array}$} & \multirow{2}{*}{$\begin{array}{l}\text { Angle between } \\
\text { Hole and Fault }\end{array}$} & \multicolumn{2}{|c|}{$\begin{array}{l}\text { Coordinates of } \\
\text { Drill Hole } \\
\text { (UTM* zone 12) }\end{array}$} \\
\hline & $\mathrm{m}$ & $\mathrm{ft}$ & & & & & $x$ & $Y$ \\
\hline Borehole 1 & 99.6 & 326 & $30^{\circ}, 134^{\circ}$ & 59.67 & 38.7 & $51^{\circ}$ & 545802 & 4332668 \\
\hline Borehole 2 & 62.8 & 206 & $0^{\circ}$ & 59.15 & 37.3 & $30^{\circ}$ & 545803 & 4332669 \\
\hline Borehole 3 & 68.3 & 224 & $0^{\circ}$ & 58.74 & 38.4 & $30^{\circ}$ & 545803 & 4332669 \\
\hline Borehole 4 & 63.1 & 207 & $10^{\circ}, 75^{\circ}$ & 47.44 & 33.5 & $40^{\circ}$ & 544679 & 4332251 \\
\hline Borehole 5 & 62.2 & 204 & $0^{\circ}$ & 47.26 & 33.5 & $30^{\circ}$ & 544679 & 4332250 \\
\hline
\end{tabular}

*UTM = universal transverse Mercator.

coring tools, and $\mathrm{BH} 4$ and $\mathrm{BH} 5$ were drilled using a double-tube tool to improve recovery. The core was oriented using a three-scribe tool, and borehole orientations were photographically recorded at twominute intervals by Layne Christensen Services.

The fault at site 1 has 3-5 m of slip and represents an example of a subseismic fault that could be hydraulically significant in a reservoir system. At site 1, two vertical boreholes and one borehole inclined at $70^{\circ}$ were collared within the Carmel Formation (Table 1). $\mathrm{BH} 2$ and $\mathrm{BH} 3$ penetrate the fault zone approximately 7.5 and $15 \mathrm{~m}$, respectively, along-strike from $\mathrm{BH}$. Here the fault offsets the upper, crossbedded unit of the Navajo Sandstone against the middle, massive, fine-grained unit (Thomas et al., 2000). Two boreholes were drilled at site 2; $\mathrm{BH} 4$ was inclined at $90^{\circ}$, and $\mathrm{BH} 5$ was vertical. Eight meters of slip is measured at site 2 . At this site, the erosionally resistant fault zone is exposed in a dry wash and cliff face within the Navajo Sandstone. BH4 and BH5 penetrate the fault along a dip line approximately $1.5 \mathrm{~m}$ apart at 47.5 true vertical depth (TVD) (Table 1). At this point the fault offsets the middle, massive sandstone against the lower, cross-bedded unit (Thomas et al., 2000).

Drill core recovery and structural logging (including core photographs) was conducted in the field. The drill core was either washed in the $\mathrm{lab}(\mathrm{BH} 1, \mathrm{BH} 2$, and $\mathrm{BH} 3)$ or in the field (BH4 and BH5). Subsequent detailed logging was done in the lab. The structural logging consisted of numbering each fracture and fault, noting its relative and absolute orientations calculated (with respect to the scribe marks and with respect to north). The tops of each drill hole were surveyed, and the downhole surveys were rectified to northing, easting, and vertical down coordinates. Depths were reported in feet and subsequently converted to SI units.
All depths have been corrected to TVD in meters, and thicknesses are measured perpendicular to the fault zone.

\section{STRUCTURAL ANALYSIS}

We identified four major structural and corresponding permeability components of the fault zone on the basis of the core logs: the host rock, single deformation bands, the fault core, and slip surfaces (Figures 4, 5). Single deformation bands appear as pale-colored planar structures that offset bedding. Relatively isolated deformation bands give way to clusters of deformation bands and then to a pale-colored fault core composed of densely packed, anastomosing deformation bands (Figure 2a). In each borehole we observe one or two extremely narrow (less than several millimeters thick), typically dark, slip surfaces. These typically lie at the edge, or in places within, the fault core. Some subsidiary clusters within the damage zone also contain slip surfaces. This deformation style matches that seen at the surface in cliff outcrops and in the base of the Big Hole wash (Shipton and Cowie, 2001). All of the faultzone components are observed in each drill hole, although the distribution of each of these components varies between the holes (Figure 4; Table 2).

In outcrop, the narrow slip surface is typically associated with poorly indurated fault rock or an open fracture (Figure $2 \mathrm{~b}$ ). It was previously unclear if cement had been weathered out of these fractures, leaving them open, or if they were open in the subsurface. Such an open fracture could greatly enhance permeability (Antonellini and Aydin, 1994). In BH3 and $\mathrm{BH} 4$, the slip surface is contained within a highly indurated and tight fault core, whereas in $\mathrm{BH} 1, \mathrm{BH} 2$, and $\mathrm{BH} 5$, broken core (poor core recovery) or an open 
Site 1

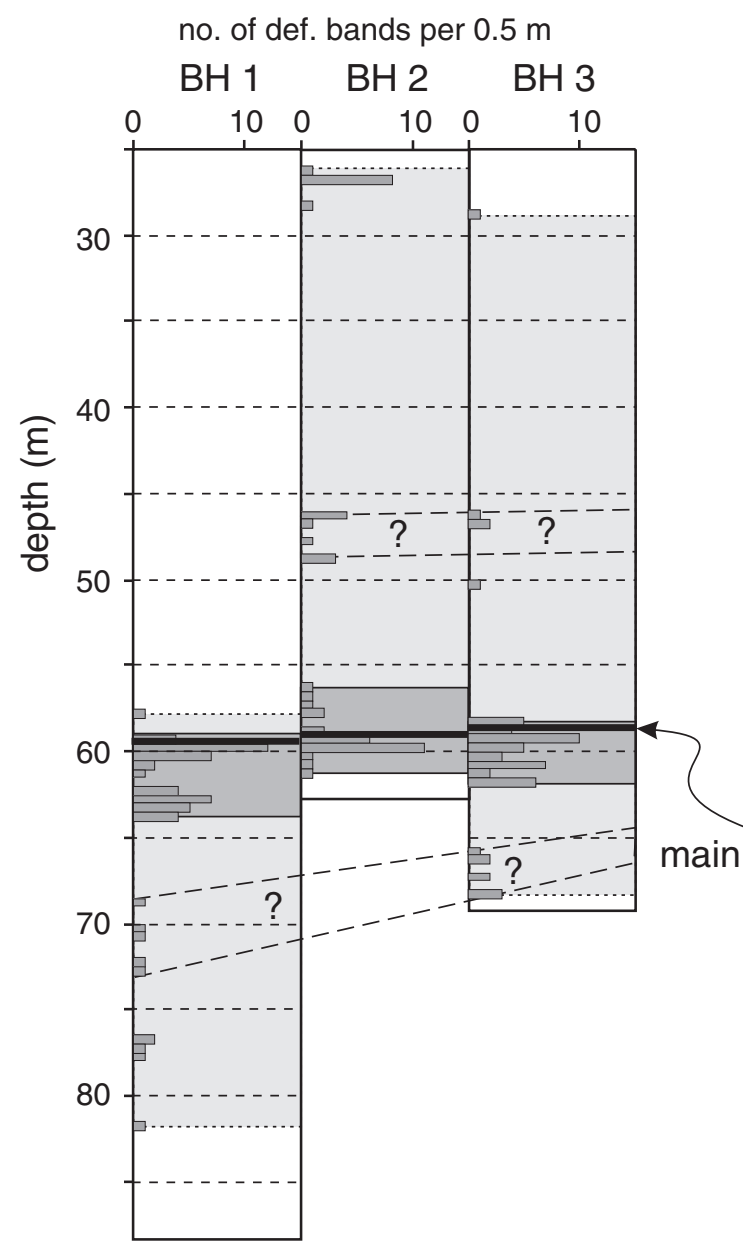

\section{Site 2}

no. of def. bands per $0.5 \mathrm{~m}$ $\mathrm{BH} 4 \quad \mathrm{BH} 5$

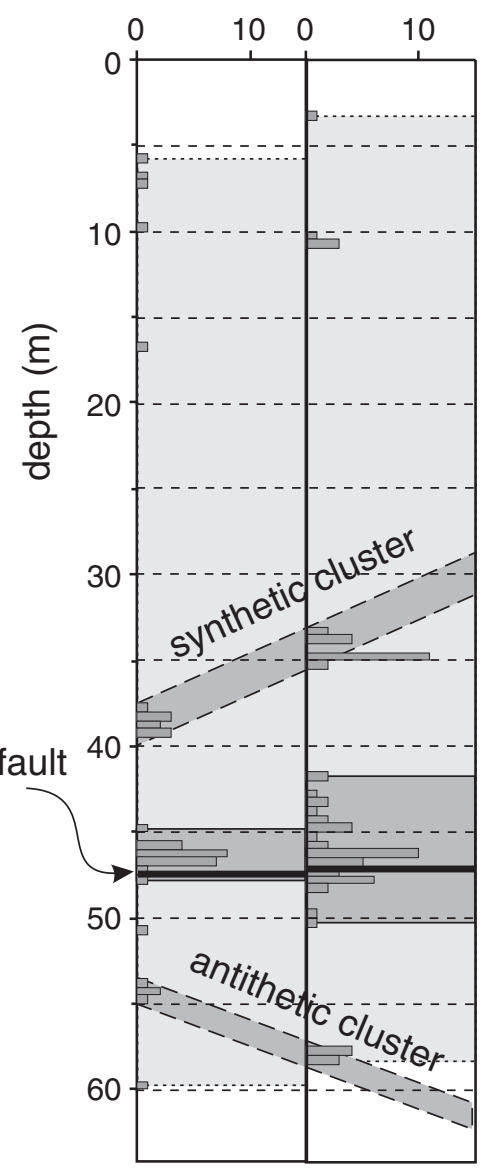

Figure 4. Frequency of deformation bands logged in the cores of the five boreholes. At site 1, the boreholes encountered slip surfaces at about $59 \mathrm{~m}$ (dark line). The fault is surrounded by a cluster of deformation bands (dark shaded region). Two other indistinct clusters can be correlated between some of the boreholes (dashed lines). At site 2, the main slip surfaces were encountered around $47 \mathrm{~m}$. Synthetic and antithetic deformation band clusters (dark shading) were encountered in the hanging wall and footwall of the fault zone. Pale gray shading indicates the damage zone as defined by the first and last deformation bands encountered in the hole. Depth is true vertical depth (TVD). mode fracture exists along the slip surface. This shows that slip surfaces can be either tightly sealed or open fractures at depth.

At site 1, fault core thicknesses range from 6 to 32 $\mathrm{cm}$ and damage zone thicknesses from 11.5 to $19.8 \mathrm{~m}$ (Figure 4). BH2 had the widest fault core and $\mathrm{BH} 3$ the widest damage zone, but little variability existed between the three holes. No subsidiary deformation band clusters are observed in the hanging wall in $\mathrm{BH} 1$, but a cluster at $47.5 \mathrm{~m}$ in $\mathrm{BH} 2$, which contains a slip surface, can be correlated to a smaller cluster in BH3. A rather indistinct cluster in $\mathrm{BH}$ could be correlated to a cluster in $\mathrm{BH} 3$ at $67.5 \mathrm{~m}$. BH2 did not penetrate deep enough to hit this cluster. The maximum frequency of deformation bands in and near the fault zone is 10-12 per $0.5 \mathrm{~m}$ in all holes (Figure 4).

At site 2, the fault core thickness is $33 \mathrm{~cm}$ in $\mathrm{BH} 4$ and $14 \mathrm{~cm}$ in BH5, essentially the same as at site 1 . Damage zone thickness is between 26.7 and $27.4 \mathrm{~m}$, lower than at site 1 . A cluster of deformation bands is encountered in the hanging wall of the fault in $\mathrm{BH} 4$ and BH5. This is seen higher in BH5 (34 m) than in BH4 (39 m), implying that this cluster is synthetic to the main fault zone. These deformation bands lie about $2.6 \mathrm{~m}$ perpendicular to the main Big Hole fault. Another, probably antithetic, cluster of deformation bands is seen in the footwall between 55 and $57 \mathrm{~m}$ (Figure 4). The maximum frequency of deformation bands in and near the fault zone is $10-12$ per $0.5 \mathrm{~m}$ in all holes (Figure 4).

Structures measured in the drill holes have a much wider scatter in orientation than at the surface. In general, the drill core orientation data contain a dominant set subparallel to the main fault; however, a significant number of deformation bands are oriented at high angles to the main fault, an orientation not seen in surface outcrops. These are probably due to poor alignment of the core with respect to the orientation scribes or 
Figure 5. Selected borehole geophysical data compared to structural frequency and probe permeameter data from (a) $\mathrm{BH} 3$ and (b) $\mathrm{BH} 5$. The fault zone is expressed as a 2-3 m-wide signal in the geophysical data. Low primary porosity in bounding surfaces between the different sandstone units produces a similar geophysical signature to that of the fault. Depth is true vertical depth (TVD). (a)

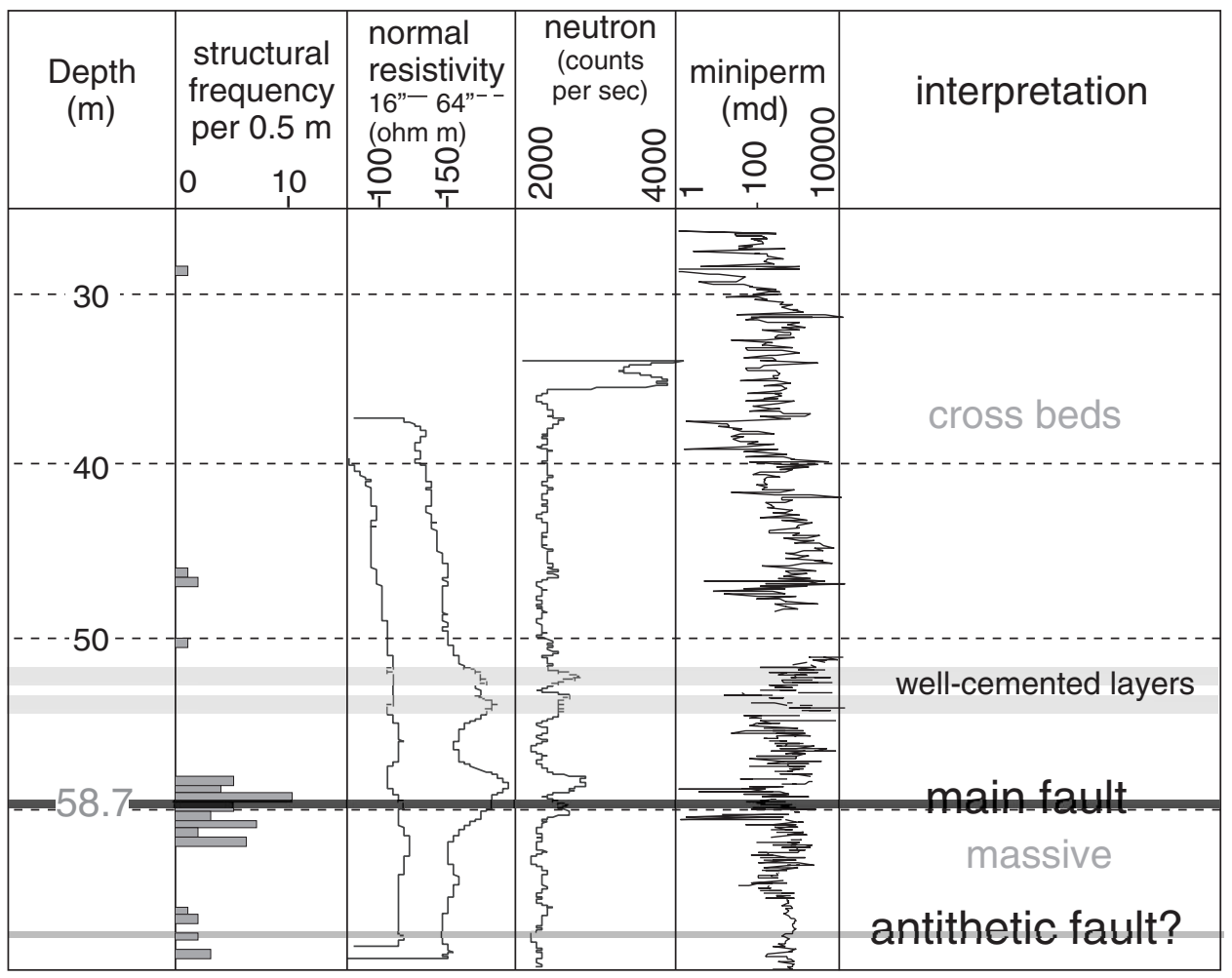

(b)

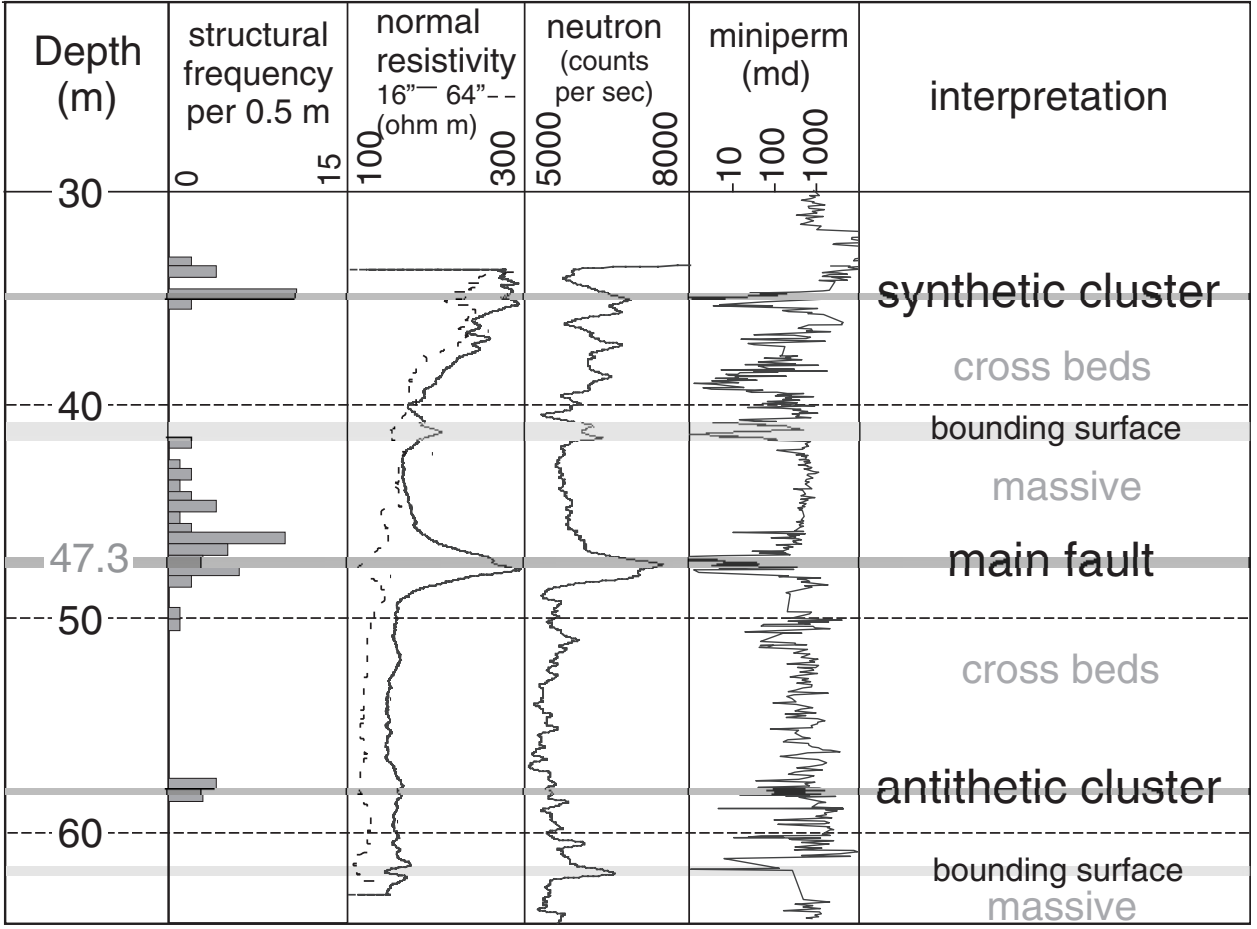

variability of the scribe marks (twisting) down the core. This demonstrates the difficulty in determining the orientation of faults and fractures even in shallow ori- ented core. No difference in orientation is seen between site 1 and site 2, but this is as likely to be due to the poor quality of the data as to any real informa- 
Table 2. Position and Thickness of Fault Zone Units from Core Logging*

\begin{tabular}{|c|c|c|c|c|c|c|}
\hline & & Borehole 1 & Borehole 2 & Borehole 3 & Borehole 4 & Borehole 5 \\
\hline \multicolumn{7}{|c|}{ True Vertical Depth (m) } \\
\hline \multirow{7}{*}{\multicolumn{2}{|c|}{$\begin{array}{l}\text { first deformation band } \\
\text { top of fault cluster } \\
\text { top of fault core } \\
\text { fault plane } \\
\text { base of fault core } \\
\text { base of fault cluster } \\
\text { last deformation band }\end{array}$}} & 58.51 & 26.07 & 28.35 & 5.50 & 3.30 \\
\hline & & 58.84 & 55.87 & 57.57 & 45.59 & 41.82 \\
\hline & & 59.54 & 57.29 & 58.69 & 46.79 & 47.03 \\
\hline & & 59.67 & 59.15 & 58.74 & 47.44 & 47.26 \\
\hline & & 59.78 & 57.93 & 58.82 & 47.44 & 47.31 \\
\hline & & 63.37 & 60.90 & 61.46 & 47.99 & 50.23 \\
\hline & & 81.41 & 60.90 & 67.86 & 58.82 & 58.18 \\
\hline \multicolumn{7}{|l|}{ Thickness (m) } \\
\hline \multirow[t]{2}{*}{ fault core } & vertical & 0.24 & 0.64 & 0.13 & 0.65 & 0.28 \\
\hline & true & 0.12 & 0.32 & 0.06 & 0.33 & 0.14 \\
\hline \multirow[t]{3}{*}{ fault cluster } & vertical & 4.53 & 5.03 & 3.89 & 2.40 & 8.41 \\
\hline & true & 2.27 & 2.52 & 1.94 & 1.20 & 4.20 \\
\hline & no. of deformation bands & 47 & 27 & 42 & 22 & 43 \\
\hline \multirow[t]{3}{*}{ damage zone } & vertical & 22.90 & 34.83 & 39.51 & 53.32 & 54.88 \\
\hline & true & 11.45 & 17.42 & 19.75 & 26.66 & 27.44 \\
\hline & no. of deformation bands & 54 & 47 & 55 & 43 & 74 \\
\hline
\end{tabular}

*Fault core $=$ zone of tightly packed deformation bands adjacent to the main slip-surface; fault cluster = deformation bands immediately around the fault core (not including subsidiary clusters); damage zone $=$ all the deformation from first to last deformation band seen in the core.

tion on deformation band geometry within the damage zone.

\section{Borehole Geophysics}

Only a summary of the geophysical well-log data is provided here (Figure 5). Neutron, sonic velocity, 16" and 64" normal resistivity, and density-based porosity, gamma-ray, single point resistivity (SPR), spontaneous potential, induction, borehole televiewer, and calliper logs were run. From analysis of these logs we have been able to identify and distinguish the petrophysical signature of the fault-zone components and the stratigraphic units.

The fault zone correlates well with an increase in $16^{\prime \prime}$ normal resistivity, SPR, spontaneous potential, and neutron logs and sonic velocity responses. These logs ramp up to a peak value from the hanging-wall side of the fault and drop sharply in the footwall side. A value for porosity can be calculated from these logs (with corrections for calibration errors) (R. Jarrard, 1998, 1999, 2000, personal communication). In general, the fault-zone porosity is $15-20 \%$ less than the host rock porosity (i.e., fault-zone porosity is $3-9 \%$ ), which agrees with the results of Hood and Patterson (1984) and Shipton and Cowie (2001). Sonic velocities of the host rock range from 2.5 to $3.0 \mathrm{~km} / \mathrm{sec}$ and the fault zone exhibits an increase to $4-4.5 \mathrm{~km} / \mathrm{sec}$. No enhanced porosity is evident in the fault zone in any of the holes. The width of the low-porosity region defined from well logs is greater than that identified from structural logging. The two sites exhibit slight differences in the shape of the log signature, indicating that $\mathrm{BH} 4$ and BH5 encountered a slightly wider zone of reduced porosity, in agreement with the structural logging.

Many of the stratigraphic elements observed in the drill core can also be correlated with the well logs. For instance, in $\mathrm{BH} 5$ the difference between the crossbedded unit, underlying massive beds, and lower crossbedded unit can be seen in the neutron log (Figure 5b). The uniform signature of the massive unit presumably reflects a uniform fine grain size in these beds. A zone of reduced porosity between the upper cross-bedded unit and the massive sandstone (Figure $5 b$ ) may correspond to a sedimentary bounding surface (Thomas et al., 2000). This and other well-cemented host rock layers (Figure 5a) show similar size signal in the well logs as the fault zone. Gamma-ray logs indicate very low clay contents, consistent with clean sandstones. In general, porosity decreases down the boreholes. 


\section{PERMEABILITY MEASUREMENTS}

We examined the fault-related permeabilities at three scales. A probe permeameter was used to investigate permeability variations at a centimeter scale along each drill core. Because these data are continuous, they provide a window of investigation over the thickness of the fault and fault-affected host rock (10-15 m scale) (see Chandler et al., 1989; Hurst and Goggin, 1995). Permeability measurements on whole-core samples (decimeter scale) provide insights into permeability anisotropy, the permeability at confining pressures, and the permeability $(k)$ of individual fault components.

\section{Probe Permeameter Tests}

Probe permeameter measurements (Hurst and Goggin, 1995) were taken at $3 \mathrm{~cm}$ intervals (Figures 5, 6). A thin slice was cut from the core to provide a flat surface for testing while preserving the bulk of the core for subsequent whole-core testing. The measurement range of the probe permeameter is from 0.1 to 10,000 $\mathrm{md}$, with an accuracy of about $0.1 \%$. Steady-state tests were performed by flowing nitrogen gas through airdried samples with an approximate volume of $1 \mathrm{~cm}^{3}$. In our raw data sets, values greater than $10,000 \mathrm{md}$
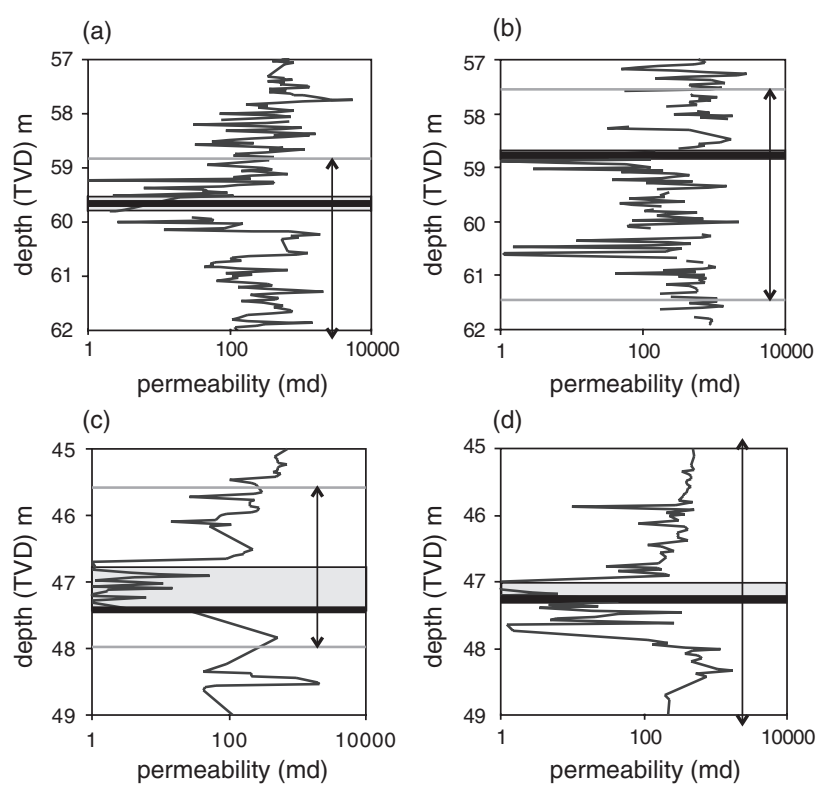

Figure 6. Details of probe permeameter data at $3 \mathrm{~cm}$ spacing from near to the fault zone. The fault zone is marked by solid lines, and the fault core by gray boxes. The top and base of the fault core cluster (Table 2) are marked by gray lines and arrows. (a) $\mathrm{BH} 1$, (b) $\mathrm{BH} 3$, (c) $\mathrm{BH} 4$, (d) $\mathrm{BH}$. were represented by 4 or 5 measurements. These high values are likely due to a poor seal between the sample and the probe permeameter or testing of an open bedding plane. These values were, therefore, not included in our subsequent data analysis.

The fault zone is expressed as a narrow, lowpermeability zone that correlates well with the position of the fault core determined from the structure logs (Figure 5). Permeability declines from $1000 \mathrm{md}$ to below the resolution of the instrument near the fault core or deformation bands. Below the fault zone we observed a return to background values of permeability in the range of 100-1000 md. The host sandstones exhibit reductions of permeability to 5-10 md over $20 \mathrm{~cm}$ of core distance. Fault core measurements showed permeability values ranging from 1 to $44 \mathrm{md}$, but with a preponderance of values around 1 or $2 \mathrm{md}$ (Figure 6). Measurements where the permeameter nozzle hit deformation bands showed values of permeability ranging from 1 to $134 \mathrm{md}$, but with a preponderance of values around $10 \mathrm{md}$. This value does not reflect the true values of permeability for deformation bands because the probe permeameter nozzle is wider than an individual deformation band, so it also tests some of the host rock volume around the deformation band.

The tested intervals also exhibited the influence of primary sedimentary structure (Figures 5,6 ). Numerous high-permeability zones, some greater than 8000 md, are from poorly cemented, high-porosity eolian cross-bedding surfaces. The sandstone in $\mathrm{BH} 4$ and $\mathrm{BH} 5$ displays a broad band of nearly homogeneous permeability above the fault zone. This is in the middle, more massive, member of the Navajo Sandstone (Figure 5). Low-permeability bounding surfaces have permeability signatures that are very similar to those of the main fault core. The host rock permeabilities measured here agree well with other data on the Navajo Sandstone in the region (Hood and Patterson, 1984).

\section{Whole-Core Permeability Measurements}

We measured the permeability of whole-core samples over a range of pressures in triaxial conditions. This highlights how anisotropy within the samples, such as deformation band intensity and orientation and the character and orientation of sedimentary structures, affects permeability anisotropy. These data also provide more information on the permeability of different fault-zone components. Permeability was measured in three orientations, along the sample axis $\left(k_{\mathrm{v}}\right)$, normal 
to the sample axis and perpendicular to the flat slabbed face $\left(k_{0}\right)$, and normal to the sample axis and parallel to the flat face $\left(k_{90}\right)$ (Figure 7$)$, at a confining pressure of $400 \mathrm{psi}(2.8 \mathrm{MPa})$. Probe permeameter measurements were taken at $0.6 \mathrm{~cm}$ spacing on the whole-core samples. The values obtained for each whole-core sample typically fall within the range of the probe permeameter values, but where they deviate they can be explained, in part, by assessing the detailed internal structure of each whole-core sample.

The whole-core samples are $9.5 \mathrm{~cm}$ long and 5.8 $\mathrm{cm}$ in diameter (Figure 7a). Two samples contained structures; the other three tested the host rock. Sample BH3-1 is from within the fault core and comprises a dense network of deformation bands at $23^{\circ}$ from the sample axis (Figure 7b). Sample BH2-1 (Figure 7c) contains a single deformation band oriented at $23^{\circ}$ to the sample axis. Sedimentary stratification is difficult to discern in the faulted samples. The unfaulted sam- ples include a sample that has poorly defined stratification (BH1-1, Figure 7d), a sample that has cross stratification at $80^{\circ}$ to the sample axis (BH3-2, Figure $7 \mathrm{e}$ ), and a weakly stratified sample that has bedding oriented about $30^{\circ}$ from the sample axis (BH3-3, Figure $7 f)$.

The fault core sample (BH3-1) yields a minimum permeability ( $1-2 \mathrm{md})$ parallel to the core axis $\left(k_{\mathrm{v}}\right)$. This corresponds to similar values obtained with the probe permeameter in the fault core. The swarm of deformation bands extends fully across the sample, thus restricting flow along the core axis (Figure $7 \mathrm{~b}$ ). The highest permeability is parallel to the intersection of the faults $\left(k_{90}=16 \mathrm{md}\right)$, which is expected because this is the direction where the relatively high permeability host rock compartments are longest and most continuous. The difference between $k_{0}$ and $k_{90}$ is relatively low $\left(k_{0}\right.$ is $84 \%$ of $k_{90}$ ), so this sample is effectively isotropic in the horizontal plane.

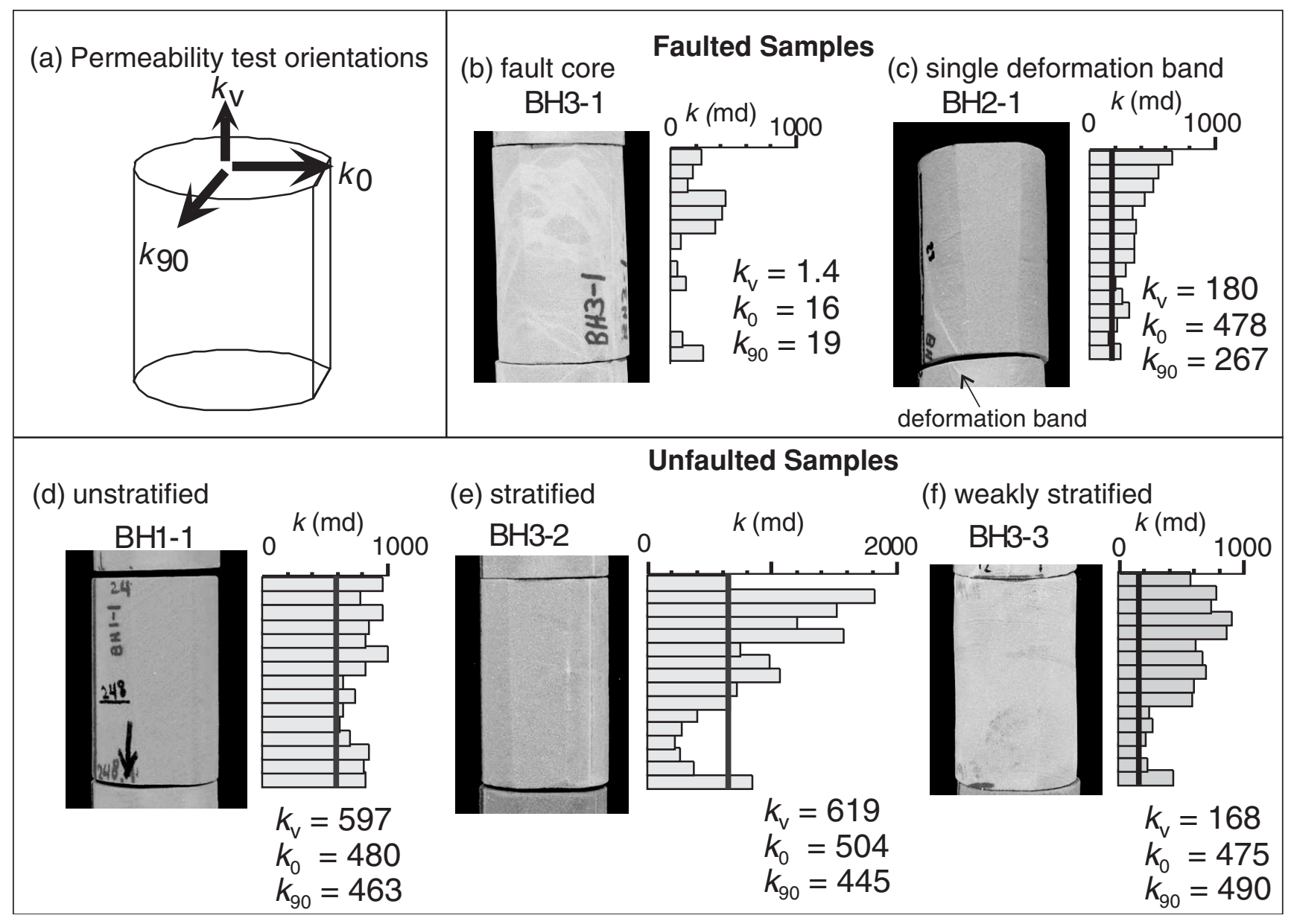

Figure 7. (a) Orientation of head gradients applied to the sample with respect to the flat edge of the sample. Illustration of test samples for $(b, c)$ the faulted samples and $(d, e, f)$ the host rock samples. The photographs are taken toward the flat face of the sample. Histograms show the probe permeameter values made at $0.6 \mathrm{~cm}$ spacing on the flat face of each sample. For reference, we show, $k_{\mathrm{v}}$ at the lowest confining pressure of $400 \mathrm{psi}(2.8 \mathrm{MPa})$ from the whole-core tests. 
In the single deformation band sample (BH2-1) the value of $k_{\mathrm{v}}$ is $180 \mathrm{md}$, reflecting the fact that the deformation band cuts across and is restricting flow through the entire sample (Figure 7c). This is an average permeability value over the entire sample. To determine the permeability of a single deformation band we use the harmonic mean of the bulk sample (Cardwell and Parsons, 1945),

$$
k_{\mathrm{db}}=\left(k_{\mathrm{av}} l_{\mathrm{db}} / l\right) /\left[1-\left(k_{\mathrm{av}} l_{\mathrm{h}} / l k_{\mathrm{h}}\right)\right]
$$

where $k_{\mathrm{db}}$ is the permeability of the deformation band, $k_{\mathrm{av}}$ is the measured permeability of the sample, $k_{\mathrm{h}}$ is the permeability of the host rock, $l$ is sample length, $l_{\mathrm{db}}$ is deformation band width $(1 \mathrm{~mm})$, and $l_{\mathrm{h}}$ is $l-$ $l_{\mathrm{db}}$. Using this method, a single deformation band has a permeability of $0.90-1.3 \mathrm{md}$, depending on the value used for host rock permeability.

The lowest permeability in the single deformation band sample is $k_{0}$ (Figure 7c). Here again the deformation band cuts across the whole sample. In the $k_{0}$ direction the fluid encounters relatively less host rock, so the bulk permeability is reduced further with respect to the host rock than in the $k_{\mathrm{v}}$ direction. The highest permeability in the deformation band sample is parallel to the deformation band strike $\left(k_{90}\right)$ and has a value of $463 \mathrm{md}$. This is still substantially lower than most of the host rock values, suggesting that the host rock near individual deformation bands is reduced in permeability. Host rock probe permeameter values in both of the faulted samples are reduced to between 211 and 555 md (Figure 7b, c), which is generally lower than the host rock probe permeameter data from the unfaulted samples (Figure 7d, e, f).

The internal structure of the host rock samples results in permeability anisotropy at the decimeter scale. The upper half of the weakly stratified sample exhibits cross stratification (Figure $7 \mathrm{f}$ ) that yields reduced permeability along the core axis $\left(k_{\mathrm{v}}\right)$. The unstratified lower half of the sample yields isotropic permeability in the plane normal to the sample axis (i.e., $k_{0}$ is $97 \%$ of $k_{90}$ ). The unstratified and stratified samples have higher permeabilities along the sample axis than normal to the axis. In both cases the apparent anisotropy is not large; thus, we consider both samples to be effectively isotropic.

\section{Confining Pressure Tests}

In the subsurface, confining pressure $\left(P_{\mathrm{c}}\right)$ has a significant effect on pore connectivity. Each of the four fault- zone components can be expected to exhibit a markedly different permeability as a function of $P_{\mathrm{c}}$ (Evans et al., 1997). To evaluate the permeability of faultrelated rocks at approximately subsurface conditions, we tested the whole-core samples for permeability over a range of $P_{\mathrm{c}}$ between 400 and 4350 psi $(2.8-30$ $\mathrm{MPa}$ ). Permeability was measured in each of the three orthogonal directions before raising the confining pressure to the next level (Figure 8). Table 3 shows the results of the confining pressure tests.

In the fault core sample (BH3-1), the value of $k_{\mathrm{v}}$ decreases only slightly with increasing confining pressure (Figure 8a). The framework of deformation bands that defines relatively high-permeability compartments is stiff, supporting the relatively undeformed host rock between them and reducing the effect of confining pressure. A larger decrease in permeability with increasing confining pressure is seen perpendicular to the faults $\left(k_{0}\right)$ : from 15 to $2 \mathrm{md}$. This is because a relatively larger proportion of host rock is affected by loading in this direction. Note that the absolute permeability values are low: compare the $y$-axes of the faulted samples (Figure 8a, b) to the unfaulted samples (Figure $8 \mathrm{c}, \mathrm{d}, \mathrm{e}$ ). The value of $k_{90}$ increases at the highest $P_{\mathrm{c}}$. This may be due to the presence of microfractures within the fault core. In the single deformation band sample (BH2-1), the values of $k_{\mathrm{v}}$ and $k_{0}$ decrease only slightly with increasing confining pressure (Figure $8 b)$. The value of $k_{90}$ also increases slightly but not by such a large percentage as in the fault core. The harmonic mean for these high confining pressures results in a $k_{\mathrm{db}}$ between 0.45 and $0.66 \mathrm{md}$.

For host rock samples, $k_{\mathrm{v}}$ changes little over the range of pressures investigated; however, $k_{0}$ and $k_{90}$ decrease by a greater amount (from 445-504 md down to $247-357 \mathrm{md}$ ). This is likely due to the dominant effects of higher permeability bedding planes, which are controlling the flow in the plane perpendicular to the sample axis. As confining pressure increases, these zones experience a reduced porosity and, thus, a reduction in permeability. The finer grained beds do not respond as much to an increase in confining pressure, so the value of $k_{\mathrm{v}}$ does not change with $P_{\mathrm{c}}$.

\section{MODELING PERMEABILITY STRUCTURE OF THE FAULT ZONE}

We apply our structural analyses and permeability results to a subsurface setting by modeling the permeability of the fault zone and determining the reduction 
Faulted samples

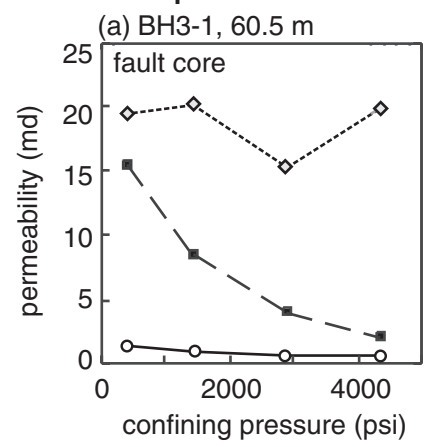

Unfaulted samples

(c) BH1-1, $75.5 \mathrm{~m}$

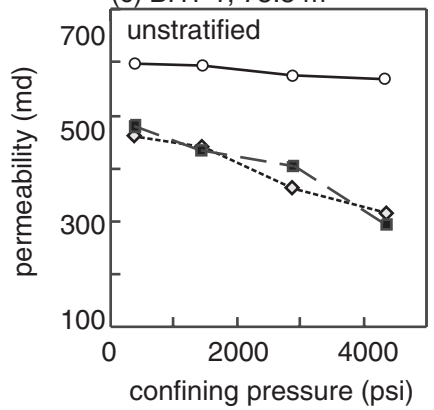

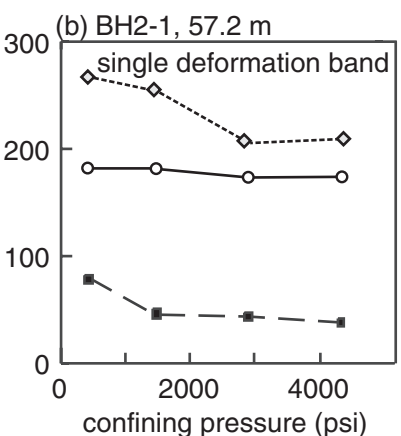

$\multimap k_{\mathrm{v}}$, along sample axis

- $k_{0}$, parallel to flat face

...ی-... $k_{90}$, perpendicular to flat face (d) $\mathrm{BH} 3-2,61.6 \mathrm{~m}$

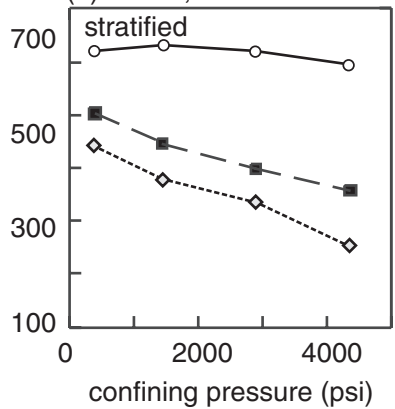

(e) BH3-3, $58.3 \mathrm{~m}$

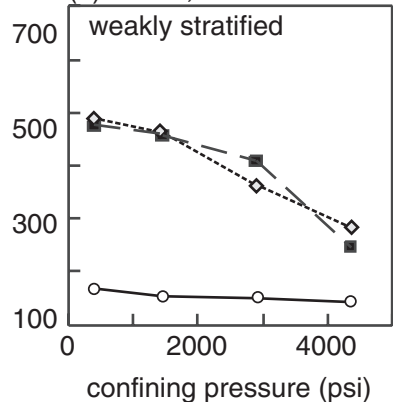

Figure 8. Variations of permeability as a function of confining pressure for (a) the fault core, (b) single deformation band, (c) unstratified host rock, (d) cross-bedded host rock, (e) weakly cross-bedded samples. Note change of $y$-axis scale between faulted and unfaulted samples. in permeability relative to the host rock. Such calculations are required to incorporate fault zones into reservoir models (Manzocchi et al., 1999). We estimate the permeability for the fault zone by considering weighted means of all the components in a grid block (Cardwell and Parsons, 1945). Although these methods were originally developed for estimation of the bulk permeability of a sedimentary package (Deutsch, 1989; Jensen et al., 1997), these analyses can equally apply to bulk permeability of a fault zone (Antonellini and Aydin, 1994). We consider three end-member effective permeability calculations for the fault zone and use the four-component system for the fault zone described previously.

Two calculations are used to estimate the permeability of components with parallel geometries, that is, layered stratigraphy or parallel fault-zone components. The weighted arithmetic mean is used to represent the permeability where flow is parallel to the fault zone. In this case

$$
k_{\mathrm{av}}=\Sigma\left(k_{i} \mathrm{~h}_{i}\right) / \Sigma h_{i}
$$

where $k_{\mathrm{av}}$ is the mean permeability, $k_{i}$ is the permeability of the $i$ th fault component, and $h_{i}$ is the thickness of the $i$ th component. For flow perpendicular to the fault, the weighted harmonic mean estimates the fault-zone permeability as

$$
k_{\mathrm{av}}=\Sigma h_{i} / \Sigma\left(h_{i} / k_{i}\right)
$$

These represent end-member permeability values of a layered system where the arithmetic mean represents $k_{\max }$ and the harmonic mean is $k_{\text {min }}$. All other effective permeabilities lie between these end members (Cardwell and Parsons, 1945).

These approaches do not represent faults with complex geometry, in which intersecting faults would concentrate flow through fault-bounded blocks of higher permeability sandstones (see Figure 7). Thus, we use an inverse power mean to consider a random system of permeability structures (Jensen et al., 1997; K. Hestir, 2000, personal communication):

$$
k_{\mathrm{av}}=\left[\Sigma 1 /\left(k_{i}\right)^{p}\right]^{1 / p}
$$

where $-1 \leq p \leq 1$. The inverse power mean is typically used to represent the bulk permeability of channel sands or other irregular sedimentary geometries (Jensen et al., 1997), but there is no physical basis for choosing $p$, and it is commonly estimated by inverting data such as pressure data. A geometric mean 
Table 3. Confining Pressure Test Results

\begin{tabular}{|c|c|c|c|c|c|c|c|c|c|}
\hline \multirow[b]{2}{*}{ Sample Number } & \multirow[b]{2}{*}{ Sample Type } & \multirow{2}{*}{$\begin{array}{l}\text { Sample } \\
\text { Depth } \\
(\mathrm{m})\end{array}$} & \multirow{2}{*}{$\begin{array}{c}\text { Sample } \\
\text { Porosity* } \\
(\%)\end{array}$} & \multirow{2}{*}{$\begin{array}{l}\text { Sample } \\
\text { Length } \\
\text { (in.) }\end{array}$} & \multirow{2}{*}{$\begin{array}{c}\text { Sample } \\
\text { Diameter } \\
\text { (in.) }\end{array}$} & \multirow{2}{*}{$\begin{array}{l}\text { Confining } \\
\text { Pressure } \\
\text { (psi) }\end{array}$} & \multicolumn{3}{|c|}{ Permeability (md) } \\
\hline & & & & & & & $k_{\mathrm{v}}$ & $k_{0}$ & $k_{90}$ \\
\hline \multicolumn{10}{|l|}{ Faulted samples } \\
\hline \multirow[t]{4}{*}{ BH3-1 } & fault core & 60.5 & 14.55 & 3.9 & 2.412 & 400 & 1.44 & 15.5 & 19.4 \\
\hline & & & & & & 1450 & 0.89 & 8.55 & 20.2 \\
\hline & & & & & & 2900 & 0.72 & 4.08 & 15.3 \\
\hline & & & & & & 4350 & 0.62 & 2.21 & 19.8 \\
\hline \multirow[t]{4}{*}{ BH2-1 } & single deformation band & 57.2 & 20.82 & 3.975 & 2.4 & 400 & 180 & 78.2 & 267 \\
\hline & & & & & & 1450 & 180 & 44.6 & 252 \\
\hline & & & & & & 2900 & 173 & 42.1 & 204 \\
\hline & & & & & & 4350 & 175 & 39.3 & 209 \\
\hline \multicolumn{10}{|l|}{ Unfaulted samples } \\
\hline \multirow[t]{4}{*}{$\mathrm{BH} 1-1$} & unstratified host rock & 75.5 & 24.25 & 3.86 & 2.383 & 400 & 597 & 480 & 463 \\
\hline & & & & & & 1450 & 595 & 433 & 440 \\
\hline & & & & & & 2900 & 578 & 405 & 362 \\
\hline & & & & & & 4350 & 570 & 292 & 315 \\
\hline \multirow[t]{4}{*}{$\mathrm{BH} 3-2$} & stratified host rock & 61.6 & 23.29 & 3.86 & 2.395 & 400 & 619 & 504 & 445 \\
\hline & & & & & & 1450 & 632 & 446 & 376 \\
\hline & & & & & & 2900 & 621 & 398 & 337 \\
\hline & & & & & & 4350 & 596 & 357 & 252 \\
\hline \multirow[t]{4}{*}{$\mathrm{BH} 3-3$} & weakly stratified host rock & 58.3 & 23.74 & 4.07 & 2.391 & 400 & 168 & 475 & 490 \\
\hline & & & & & & 1450 & 154 & 455 & 464 \\
\hline & & & & & & 2900 & 149 & 409 & 361 \\
\hline & & & & & & 4350 & 144 & 247 & 284 \\
\hline
\end{tabular}

*Porosity is measured in full diameter core holders with helium gas to determine Boyle's Law porosity.

(Deutsch, 1989) is sometimes used to find $k_{\mathrm{av}}$, but these calculations require that the variability of $k_{i}$ be lognormally distributed (Jensen et al., 1997). This condition is unlikely in our case.

The structural data logged in each core is used to determine the number and total thickness of (1) fault core, (2) undeformed rock within the damage zone, and (3) deformation bands. For these simple onedimensional calculations, we correct for the orientation of the boreholes using a Terzaghi correction (Terzaghi, 1965). The fault zone is approximated as a parallel series of low- and high-permeability zones. Thus, the analyses consider the geometry of the fault zone compatible with the end-member calculations. Our permeability data from the whole-core confining pressure tests are used to assign values for the host rock, single deformation bands, and the fault core. Permeability values for slip surfaces come from Antonellini and Aydin (1994).
The results for $k_{\mathrm{h}}$ of $600 \mathrm{md}$ are summarized in Table 4 . As expected, $k_{\mathrm{av}}$ for transverse flow yields the lowest $k_{\mathrm{av}}$ of 7-19 md and fault transmissibilities of 0.01-0.03. Because of the small fraction of rock occupied by the deformation bands and faults, and because our simplified geometry allows flow into the high $k$ zones, the arithmetic means of $k_{\mathrm{av}}$ are close to $k_{\mathrm{h}}$, and flow parallel to the fault would be little affected by the presence of the fault zone. The inverse power calculations do not explicitly incorporate any information regarding geologic structure and yield spurious results for $-1<p<0.3$. For $0.4 \leq p \leq 1$, they suggest a permeability range of 7-57 $\mathrm{md}$. The three sets of results taken together suggest a strongly anisotropic fault zone, in which flow across the fault is limited and flow parallel to the fault would be enhanced. Connected, fault-bounded regions of host rock would exhibit a baffled-flow geometry with intermediate permeability values. 
Table 4. Bulk Transverse Permeability (Using the Weighted Harmonic Mean) of Fault Zones Encountered at Each Hole

\begin{tabular}{|c|c|c|c|c|c|c|c|c|c|}
\hline \multicolumn{10}{|c|}{ Restricted Definition of Fault: Fault Zone Cluster and Dense Fault Core* } \\
\hline & $\begin{array}{l}\text { Number of } \\
\text { Deformation } \\
\text { Bands }\end{array}$ & $\begin{array}{c}\text { Host } \\
\text { Permeability } \\
\text { (md) }\end{array}$ & $\begin{array}{l}\text { Slip-Surface } \\
\text { Permeability } \\
\text { (md) }\end{array}$ & $\begin{array}{l}\text { Deformation } \\
\text { Band } \\
\text { Permeability } \\
\text { (md) }\end{array}$ & $\begin{array}{l}\text { Fault-Zone } \\
\text { Permeability } \\
\quad(\mathrm{md})\end{array}$ & $\begin{array}{l}\text { Total } \\
\text { Thickness } \\
\text { (m) }\end{array}$ & $\begin{array}{c}\text { Fault } \\
\text { Thickness } \\
\text { (m) }\end{array}$ & $\begin{array}{l}\text { Deformation } \\
\text { Band } \\
\text { Thickness } \\
(\mathrm{m})\end{array}$ & $\begin{array}{c}\text { Bulk } \\
\text { Transverse } \\
\text { Permeability } \\
\text { (md) }\end{array}$ \\
\hline Borehole 1 & 44 & 600 & 0.1 & 0.4 & 1.4 & 2.43 & 0.13 & 0.001 & 11.22 \\
\hline Borehole 2 & 25 & 600 & 0.1 & 0.4 & 1.4 & 2.2 & 0.31 & 0.001 & 7.41 \\
\hline Borehole 3 & 32 & 600 & 0.1 & 0.4 & 1.4 & 1.94 & 0.06 & 0.001 & 14.27 \\
\hline Borehole 4 & 22 & 600 & 0.1 & 0.4 & 1.4 & 1.06 & 0.29 & 0.001 & 3.88 \\
\hline Borehole 5 & 42 & 600 & 0.1 & 0.4 & 1.4 & 4.21 & 0.14 & 0.001 & 18.99 \\
\hline \multicolumn{10}{|c|}{ Damage Zone: First to Last Onset of Deformation Seen in Core** } \\
\hline Borehole 1 & 54 & 600 & 0.1 & 0.4 & 1.4 & 10.8 & 0.13 & 0.001 & 42.26 \\
\hline Borehole 2 & 46 & 600 & 0.1 & 0.4 & 1.4 & 17.3 & 0.31 & 0.001 & 46.13 \\
\hline Borehole 3 & 51 & 600 & 0.1 & 0.4 & 1.4 & 11.1 & 0.06 & 0.001 & 55.87 \\
\hline Borehole 4 & 44 & 600 & 0.1 & 0.4 & 1.4 & 12.4 & 0.29 & 0.001 & 35.71 \\
\hline Borehole 5 & 73 & 600 & 0.1 & 0.4 & 1.4 & 23.9 & 0.14 & 0.001 & 71.99 \\
\hline
\end{tabular}

${ }^{*}$ Mean bulk transverse permeability $=11.15$; standard deviation $=5.49$.

${ }^{* *}$ Mean bulk transverse permeability $=50.39$; standard deviation $=21.02$.

\section{Sensitivity Analyses}

We examined the impact of varying the characteristic fault-zone components: (1) fault core thickness, (2) deformation band permeability, (3) length scale over which the permeability is estimated (Antonellini and Aydin, 1994), and (4) host rock permeability. These may exhibit significant variability at the outcrop to oil field scale (Foxford et al., 1998; Walsh et al., 1998; Beach et al., 1999; Hesthammer and Fossen, 2000; Shipton and Cowie, 2001). The lowest permeability case, flow perpendicular to the fault zone (transverse flow), is considered for these analyses. The sensitivity analyses are performed on a fault with a geometry and number of deformation bands represented by the fault zone in $\mathrm{BH}$ (Table 2).

Increasing fault core thickness results in an exponential decline in transverse permeability, converging to a minimum of less than $5 \mathrm{md}$ for thickness greater than $0.5 \mathrm{~m}$ (Figure 9). The sharp decline for values of fault core thickness of $0-0.5 \mathrm{~m}$, combined with the variability of this parameter in our data, indicate that the short-scale fault-zone permeabilities may range from 5 to $35 \mathrm{md}$ in a given fault. Varying the number or permeability of deformation bands outside the fault core has less impact than changing fault core thickness. Reducing the value of $k_{\mathrm{db}}$ results in a sharp decline in $k_{\mathrm{av}}$ to values of much less than $1 \mathrm{md}$, and this effect is most pronounced where $k_{\mathrm{db}}$ drops below $2 \mathrm{md}$ (Figure 10). Increasing the number of deformation bands and holding all other factors constant results in dropping $k_{\mathrm{av}}$ to values of 3-4 md over the distances considered locally. The decrease of bulk permeability with an increase in the number of deformation bands is seen in the experimental data of Mair et al. (2000). They show an exponential decay of permeability across their experimental samples with increasing axial strain, which they correlate with the number of deformation bands in their sample beyond the point of failure (Mair et al., 2000).

Typically, the scale of cell blocks in numerical reservoir simulators is $10 \mathrm{~m}$ and greater (Manzocchi et al., 1999). At this cell size, the calculations consider a volume of rock with only minor volumes of faultrelated rocks. Equations 2 and 3 suggest that as the cell size is increased (effectively decreasing the fault/ host rock ratio), $k_{\mathrm{av}}$ should increase (Antonellini and Aydin, 1994). At cell sizes of 30-40 m, the bulk permeability is 2 to 3 times the values calculated at the 5-10 m scale. As the cell size increases, the impact of individual deformation bands declines and permeability linearly increases. The slope of the relationship is a function of the thickness of the fault zone, with thicker zones having a greater impact over the longer 


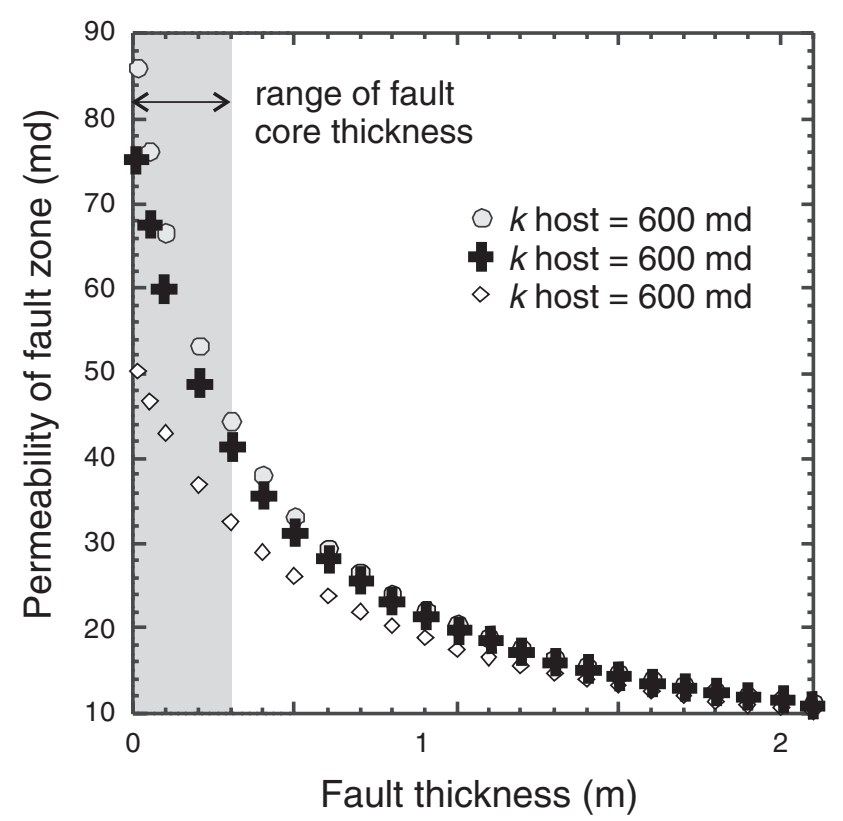

Figure 9. Calculated transverse fault permeability as a function of fault core thickness. The shaded region indicates the likely range of fault core thicknesses based on Shipton and Cowie (2001). Note the variation from 75-90 to $40 \mathrm{md}$ for the highest host rock permeability case.

distances. Variation of host rock permeability has little impact on the absolute values of bulk permeability (Figure 9), except for the case where the host rock permeability approaches the fault-zone values. This is not appropriate for modeling deformation bands in high-porosity sandstones.

\section{DISCUSSION}

\section{Fault-Zone Components}

We have used a multiscale, multifaceted approach to determine the hydraulic structure of a fault zone in eolian sandstone similar to those encountered in the subsurface, albeit at shallow depths. The data show that a four-component system best represents the Big Hole fault structure: host rock, deformation bands, fault core, and slip surfaces (Figure 11). The variability in the orientation, thickness, and permeability of each of the fault components sampled is the result of inherent variability of the system combined with the sampling bias in the boreholes. The host rock here may be one of three types, with permeability ranging between 200 and greater than $2000 \mathrm{md}$. Deformation bands exhibit a relatively small permeabil-

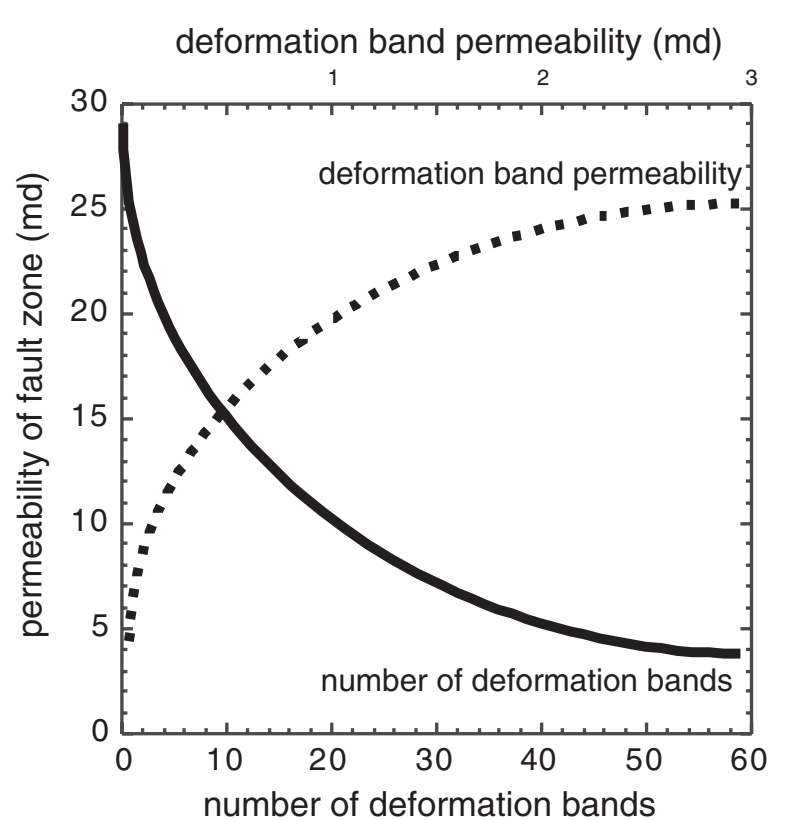

Figure 10. Bulk transverse fault permeability as a function of deformation band permeability (dotted line) or deformation band density (solid line). Increasing the number of deformation bands or decreasing the permeability of individual deformation bands reduces the bulk fault permeability.

ity variation, around $1 \mathrm{md}$, but their orientations and densities can vary. The fault core has a relatively narrow range of permeability, typically less than $1 \mathrm{md}$, but its thickness can vary dramatically over the short distances sampled in the boreholes and as seen in outcrop (Shipton and Cowie, 2001). Finally, the narrow slip surface may be either a tight zone of low permeability or may have open fractures formed along it, creating a zone of enhanced flow (not tested in these samples).

Our probe permeameter data show a permeability effect on the host rock close to the fault that has not been recognized previously in studies of deformation band evolution. Host rock within the faulted wholecore samples has permeabilities reduced by an order of magnitude with respect to the host rock away from the fault. Sample BH3-3 is from a position closer to the fault (1.5 $\mathrm{m}$ core distance) and has a lower overall permeability than the other two host rock samples. The reduced porosity signature seen in the borehole geophysics includes some host rock, not apparently cut by deformation bands. These observations indicate that some reduction of permeability occurs close to the fault. This is possibly due to fault related cementation or grain-boundary rolling that collapses porosity without changing the shape of the grains. 


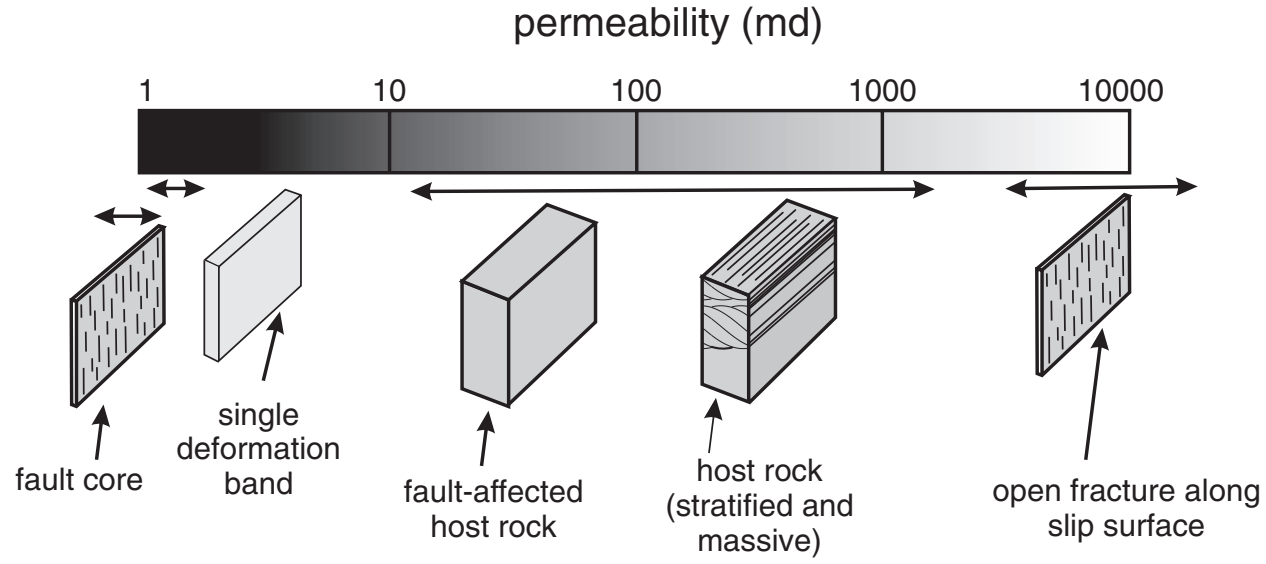

Figure 11. Synoptic diagram of fault-zone elements and the relative permeability values of each element for the Big Hole fault and protolith.
Our methods of detecting faults rely on a variety of wavelength detectors (structural logging, geophysical logging, permeameter measurements) that are tuned to different parts or dimensions of a fault (Schulz and Evans, 2000). The work discussed here indicates that in the absence of detailed geophysical logs, especially image logs (e.g., Adams and Dart, 1998), it is difficult to recognize small-deformation band faults, or to distinguish them from sedimentary features such as regional bounding surfaces. For reservoir models or the inversion of production data at the field scale, these fine-scale features may be significant.

Laboratory tests of triaxial permeability at a range of confining pressures enable us to quantify the permeability, and permeability anisotropy, of each faultzone component and to determine properties at oil field depths. Unlike other laboratory-based studies of faulted rocks, our results show that permeability has a complex dependence on confining pressure, depending on the orientation of the sedimentary and deformationinduced structures. For both the faults and low-density bedding surfaces, permeability is significantly reduced where the confining pressure shuts down the interconnected porosity.

\section{Geometry and Permeability Anisotropy}

How a fault may affect fluid flow in a sedimentary package is a function not simply of the hydraulic properties of the fault components but also their geometry. Because deformation band-dominated faults have low, but nonzero, bulk permeabilities and bound compartments of relatively undeformed host rock, flow may be communicated along or across the fault, depending on the along-strike and downdip continuity and areal extent of the fault-zone components. Continuous low- permeability faults may produce long travel paths down the pressure gradient and, therefore, support a high oil column (Knipe et al., 1997). Conversely, regions where the low-permeability fault core is narrow may provide a fast pathway for flow. The rate of flow is determined by the host rock permeability and the size of open spaces of higher permeability rock between lower permeability deformation bands. Flow along open fractures adjacent to the fault may allow flow downdip or updip along the fault. Thus, constraining the three-dimensional distribution of faultzone components is critical when attempting to assign permeability values to simulator cells.

When calculating bulk fault-zone permeability, we did not examine the effects of changes in continuity of the fault structure. The harmonic and arithmetic means model the permeability of systems with parallel permeability components, and the inverse power mean incorporates some complexity in fault geometry, but the exponent, $p$, must be determined empirically. In cases where faults are low-permeability barriers to flow, it may be more efficient to collate as much existing data on a producing field as possible (Knipe et al., 1997; Hesthammer and Fossen, 2000) and consider the likely fault structure over length scales of $10 \mathrm{~m}$ and greater (Antonellini and Aydin, 1995; Manzocchi et al., 1999). For the Big Hole fault, the fault-zone permeabilities are on the order of 10 $20 \%$ of the host rock. Modeling of the spatial distribution of the permeability structure can be developed through a process-based approach (Matthai et al., 1998), through stochastic methods (Hestir et al., 1998), or through a geostatistical approach (Deutsch, 1989). In regions where faults are conduits, this approach may be less useful, as smearing the permeability structure into an averaged value may mask 
high-permeability features that would allow premature breakthrough in a flooding project or allow communication between blocks during withdrawals.

\section{Transmissibility Multipliers}

Manzocchi et al. (1999) present analytical solutions for incorporating the fault-zone permeability into flow simulators using a transmissibility multiplier, $T$. The transmissibility multiplier is the effective permeability divided by the distance between the centers, $L$, of two cells in a flow simulator. For a simple fault where permeability of the host rock is the same on either side of the fault, the transmissibility factor is given by Manzocchi et al. (1999, equation 7):

$$
T=\left[1+\left(t_{\mathrm{f}} / L\right)\left(\left(k_{\mathrm{m}}-k_{\mathrm{f}}\right) / k_{\mathrm{f}}\right)\right]^{-1}
$$

We can examine the impact of a natural fault on a flow simulator by incorporating the results of the bulk transverse permeability of the fault zones. Using the results from boreholes 1 and 4 as examples and varying the distance between cell centers show the dramatic impact that the fault-zone thickness and the scale over which the transmissibility multiplier is calculated may have (Figure 12). The relatively thick, low-permeability fault zone reduces the value of $T$ up to distances of $100 \mathrm{~m}$ and greater, whereas the thinner, higher permeability fault has a value of $T$ of 0.9 at cell spacing of $50 \mathrm{~m}$.

\section{Fault-Zone Scaling}

For subseismic faults where little data is available, it would be ideal to have empirical relationships that describe the parameters that most affect bulk fault-zone permeability. In the past, attempts have been made to relate fault-zone thickness, $t_{\mathrm{f}}$, and displacement, $D$. In the deformation band faults we describe, the fault core and the damage zone apparently exhibit different scaling with displacement. The fault core and fault-zone cluster thickness exhibit no correlation with the amount of slip on the fault (Table 2). Complex threedimensional fault geometries mean that in some cases we may have intersected regions where the subsidiary clusters intersect, so that a wider damage zone surrounds the fault core, and vice versa. Damage zone thickness, as determined from the first deformation band recognized in the hanging wall through the ends of the drill holes, ranges from 10 to $24 \mathrm{~m}$ and does seem to correlate with the amount of displacement. This fits with the positive correlation between damage

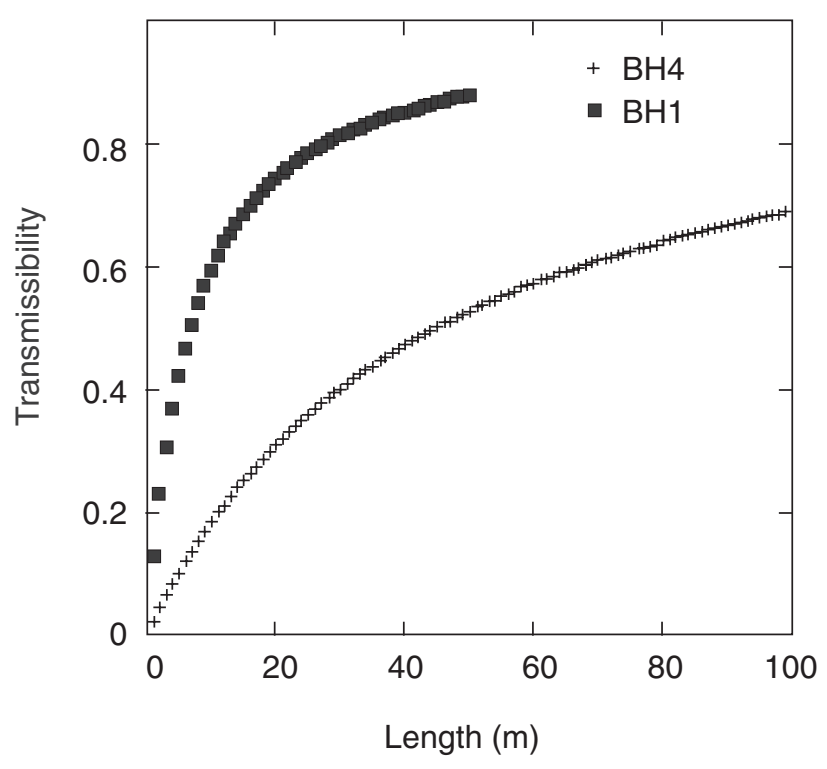

Figure 12. Transmissibility calculated for varying values of cell length for two of the boreholes for two thicknesses of fault core. Transmissibility calculated from equation 5 for the restricted definition of the fault zone for boreholes 1 and 4. Because of the differences in fault core thickness and bulk permeability calculated for each fault core, the transmissibility multiplier varies for the two holes. For a cell length of $50 \mathrm{~m}$, the fault encountered in borehole 1 effectively reduces the permeability between cell centers by only $10 \%$.

zone thickness and fault displacement seen by Shipton and Cowie (2001) in surface outcrops of the Big Hole fault.

Manzocchi et al. (1999) suggest the following empirical relationship for a variety of rock types:

$$
t_{\mathrm{f}}=D / 170
$$

This equation is the harmonic average of a variety of data sets. For our data set, this relationship would predict that the fault should be about $4.7 \mathrm{~cm}$ thick where the fault has $8 \mathrm{~m}$ of slip at site 2 , and at site 1 with 3 $\mathrm{m}$ of slip, the fault should be only $1.8 \mathrm{~cm}$ thick. Clearly, caution should be used where applying global data sets to specific cases. It may be more appropriate to restrict the use of such relationships to the specific rock types and geologic settings under consideration (Evans, 1990; Shipton and Cowie, 2001).

\section{CONCLUSIONS}

Given the importance that faults may have on fluid flow during drilling and production, marshaling all 
available data to infer the location, hydraulic properties, and structure of faults is important. We used a reservoir characterization approach, with complete core coverage, to examine a subseismic scale fault zone in eolian sandstone. Even this relatively simple system with one host rock and with one normal fault can have significant variability in the fault-zone permeability. By careful observations of drill core, probe permeameter tests, and permeability tests at confining pressures, we show that faults in eolian sandstone consist of a fourcomponent system: the host rock (and fault-affected host rock with a reduced permeability), deformation bands, the fault core, and slip surfaces. Each component exhibits its own set of structural characteristics and hydraulic parameters.

Detailed probe permeameter measurements gave values of permeability for the individual components. Deformation bands are zones of cataclasis a few millimeters wide with permeabilities of 0.9-1.3 md. Slip surfaces are planes upon which the majority of the slip has occurred, within zones of deformation bands. At the surface, they are commonly planes of parting; within our drill core samples, they may be either planes of parting or mated surfaces. The fault core consists of tightly packed deformation bands and highly crushed rock with permeability reductions down to less than 1 $\mathrm{md}$. The width of the fault core is highly variable both along-strike and downdip and cannot be correlated with the displacement on the main fault. Damage zone thickness (as determined from the first deformation band recognized in the hanging wall through the ends of the drill holes) does correlate with the amount of displacement.

The host rock exhibits considerable variability in properties, despite being within one unit of eolian sandstone. We have characterized three main subfacies within the Navajo Sandstone, each with distinct petrophysical characteristics. Upper cross-bedded units have permeabilities from 50 to $2000 \mathrm{md}$, reflecting their heterogeneous nature; middle, massive units have permeability values from 5 to $800 \mathrm{md}$, reflecting their fine-grained nature; and lower cross stratified units have permeability values from 100 to $3000 \mathrm{md}$, reflecting their coarse-grained nature. Wire-line log signatures show a reduction of porosity near the fault zone from 20 to less than $10 \%$, values that correlate well with the other data. The low-porosity zone is wider than the fault zone identified in the core. This suggests that there is a zone of host rock around the fault zone that has reduced porosity. Some stratigraphic horizons, notably bounding surfaces between the three units, have geophysical expressions very similar to that of the fault zone. These results emphasize the usefulness of core or image log data in identifying the fault-zone and stratigraphic components.

Using three methods of averaging permeability on a grid block scale, we examined bulk fault-zone permeability and permeability anisotropy. We estimate the transverse fault-zone permeability to be 7-57 md for the faults sampled by our boreholes. Sensitivity analyses show that bulk fault-zone permeability is most dependant on the thickness of the fault core, suggesting that where present, such fault cores should be identified and thicknesses estimated for use in reservoir simulators.

This work clearly shows that subseismic faults in porous sandstones, if connected, can significantly affect the permeability of the system. Identifying the faultzone components and their properties are critical in determining the bulk hydraulic properties of the fault zone. Analyses of the subseismic part of the Big Hole fault show that faults with small displacements can have a significant reduction in permeability and thus affect the hydraulic properties of a reservoir. Our site is an analog for other faulted eolian sequences, and our work outlines an integrated approach for quantifying the in-situ hydraulic fault-zone properties using similar types of data in a producing region. This approach should be useful regardless of the rock type.

\section{REFERENCES CITED}

Adams, J. T., and C. Dart, 1998, The appearance of potential sealing faults on borehole images, in G. Jones, Q. J. Fisher, and R. J. Knipe, eds., Faulting, fault sealing, and fluid flow in hydrocarbon reservoirs: Geological Society Special Publication 147, p. $71-86$.

Antonellini, M., and A. Aydin, 1994, Effect of faulting on fluid flow in porous sandstones: petrophysical properties: AAPG Bulletin, v. 78, p. $355-377$.

Antonellini, M., and A. Aydin, 1995, Effect of faulting on fluid flow in porous sandstones: geometry and spatial distribution: AAPG Bulletin, v. 79, p. 642-671.

Antonellini, M., A. Aydin, and L. Orr, 1999, Outcrop aided characterisation of a faulted hydrocarbon reservoir: Arroyo Grande oil field, California, USA, in W. C. Haneberg, P. S. Mozley, C. J. Moore, and L. B. Goodwin, eds., Faults and subsurface fluid flow: American Geophysical Union Geophysical Monograph 113, p. 7-26.

Aydin, A., 1978, Small faults formed as deformation bands in sandstone: Pure and Applied Geophysics, v. 116, p. 913-929.

Aydin, A., and A. M. Johnson, 1978, Development of faults as zones of deformation bands and as slip-surfaces in sandstones: Pure and Applied Geophysics, v. 116, p. 931-942.

Beach, A., A. I. Welbon, P. J. Brockbank, and J. E. McCallum, 1999, Reservoir damage around faults: outcrop examples from the Suez rift: Petroleum Geoscience, v. 5, p. 109-116. 
Caine, J. S., J. P. Evans, and C. B. Forster, 1996, Fault zone architecture and permeability structure: Geology, v. 18, p. 10251028.

Cardwell, W. T., and R. I. Parsons, 1945, Average permeability of heterogeneous sands: Transactions of the American Institute of Mining Engineers, v. 160, p. 34-42.

Chandler, M. A., G. Kocurek, D. J. Goggin, L. W. Lake, 1989, Effects of stratigraphic heterogeneity on permeability in aeolian sandstone sequence, Page Sandstone, northern Arizona: AAPG Bulletin, v. 75, p. 658-668.

Chester, F. M., and J. M. Logan, 1986, Implications for mechanical properties of brittle faults from observations of the Punchbowl fault zone, California: Pure and Applied Geophysics, v. 124, p. $79-106$

Conway, M. W., R. D. Barree, J. Hollingshead, C. Willis, and M. Farrens, 1997, Characterization and performance of injection wells in the Wingate and Navajo sandstones: Proceedings of the International Coalbed Methane Symposium, p. 467-480.

Deutsch, C., 1989, Calculating effective absolute permeability in sandstone/shale sequences: Society of Petroleum Engineers Formation Evaluation, v. 4, p. 343-348.

Edwards, H. E., A. D. Becker, and J. A. Howell, 1993, Compartmentalization of an aeolian sandstone by structural heterogeneities: Permo-Triassic Hopeman Sandstone, Moray Firth, Scotland, in C. P. North and D. J. Prosser, eds., Characterization of fluvial and aeolian reservoirs: Geological Society Special Publication 73, p. 339-365.

Evans, J. P., 1990, Thickness-displacement relationships for fault zones: Journal of Structural Geology, v. 12, p. 1061-1065.

Evans, J. P., C. B. Forster, and J. V. Goddard, 1997, Permeabilities of fault-related rocks and implications for fault-zone hydraulic structure: Journal of Structural Geology, v. 19, p.1393-1404.

Fisher, Q., and R. J. Knipe, 1998, Fault sealing processes in siliciclastic sediments, in G. Jones, Q. J. Fisher, and R. J. Knipe, eds., Faulting, fault sealing, and fluid flow in hydrocarbon reservoirs: Geological Society Special Publications 147, p. 117133.

Fossen, H., and J. Hesthammer, 2000, Possible absence of small faults in the Gulfaks field, northern North Sea: implications for downscaling of faults in some porous sandstones: Journal of Structural Geology, v. 22, p. 851-863.

Fouch, T. D., T. F. Lawton, D. J. Nichols, W. B. Cashion, and W. A. Cobban, 1983, Patterns and timing of synorogenic sedimentation in Upper Cretaceous rocks of central and northeast Utah, in M. W. Reynolds and E. D. Dolly, eds., Mesozoic paleogeography of the west-central United States: Rocky Mountain Paleogeography Symposium, v. 2, p. 305-336.

Foxford, K. A., J. J. Walsh, J. Watterson, I. R. Gardner, S. C. Guscott, and S. D. Burley, 1998, Structure and content of the Moab fault zone, Utah, USA and its implications for fault seal predictions, in G. Jones, Q. J. Fisher, and R. J. Knipe, eds., Faulting, fault sealing, and fluid flow in hydrocarbon reservoirs: Geological Society Special Publications 147, p. 87-103.

Gibson, R. G., 1994, Fault-zone seals in siliciclastic strata of the Columbus Basin, offshore Trinidad: AAPG Bulletin, v. 78, p. 1372-1385.

Gibson, R. G., 1998, Physical character and fluid-flow properties of sandstone-derived fault zones, in M. P. Coward, T. S. Daltaban, and H. Johnson, eds., Structural geology in reservoir characterization: Geological Society Special Publications 127, p. 83-97.

Gilluly, J., 1929, Geology and oil and gas prospects of parts of the San Rafael Swell and some adjacent areas in Utah: U.S. Geological Survey Bulletin 806C, p. 69-130.

Hesthammer, J., and H. Fossen, 2000, Uncertainties associated with fault sealing analysis: Petroleum Geoscience, v. 6, p. 37-45.

Hestir, K., S. J. Martel, S. Vail, J. C. S. Long, P. D'Onfro, and W. D.
Rizer, 1998, Inverse hydrologic modelling using stochastic growth algorithms: Water Resources Research, v. 34, p. 33353348.

Hood, J. W., and D. J. Patterson, 1984, Bedrock aquifers in the northern San Rafael Swell area, Utah, with special emphasis on the Navajo Sandstone: State of Utah Department of Natural Resources Technical Publication 78, $128 \mathrm{p}$.

Hurlow, H. A., 1998, The geology of the central Virgin River basin, southwestern Utah, and its relation to ground water conditions: Utah Geological Survey publication WRB-26, 53 p.

Hurst, A., and D. Goggin, 1995, Probe permeametry; an overview and bibliography: AAPG Bulletin, v. 79, p. 463-473.

Jensen, J. L., L. W. Lake, P. W. M. Corbett, and D. J. Goggin, 1997, Statistics for petroleum engineers and geoscientists: Englewood Cliffs, New Jersey, Prentice Hall PTR, 390 p.

Knipe, R. J., et al., 1997, Fault seal analysis: successful methodologies, applications, and future directions, in P. Moeller-Pederson and A. G. Koestler, eds., Hydrocarbon seals, importance for exploration and production: Norsk Petroleum Society Special Publication 7, p. 15-38.

Krantz, R. W., 1988, Multiple fault sets and three-dimensional strain: theory and application: Journal of Structural Geology, v. 10 , p. $225-237$.

Lawton, T. F., 1986, Fluvial systems in the Upper Cretaceous Mesaverde Group and Paleocene North Horn Formation, central Utah: a record of transition from thin-skinned to thick-skinned deformation in the foreland region, in J. A. Peterson, ed., Paleotectonics and sedimentation in the Rocky Mountain region: AAPG Memoir 41, p. 423-442.

Mair, K., I. Main, and S. Elphick, 2000, Sequential growth of deformation bands in the laboratory: Journal of Structural Geology, v. 22 , p. $25-42$.

Manzocchi, T., J. J. Walsh, P. Nell, and G. Yielding, 1999, Fault transmissibility multipliers for flow simulation models: Petroleum Geoscience, v. 5, p. 53-63.

Matthai, S. K., A. Aydin, D. D. Pollard, and S. G. Roberts, 1998, Numerical simulation of departures from radial drawdown in faulted sandstone reservoir with joints and deformation bands, in G. Jones, Q. J. Fisher, and R. J. Knipe, eds., Faulting, fault sealing, and fluid flow in hydrocarbon reservoirs: Geological Society Special Publication 147, p. 157-192.

Morgan, C. D., and T. C. Chidsey Jr., 1991, Gordon Creek, Farnham Dome, and Woodside fields, Carbone and Emery counties, Utah, in T. C. Chidsey Jr., ed., Geology of east-central Utah: Utah Geological Association Guidebook 19, p. 301310 .

Ottesen Ellevset, S., R. J. Knipe, T. Svava Olsen, Q. J. Fisher, and G. Jones, 1998, Fault-controlled communication in the Sleipner Vest field, Norwegian continental shelf, detailed quantitative input for reservoir simulation and well planning, in G. Jones, Q. J. Fisher, and R. J. Knipe, eds., Faulting, fault sealing, and fluid flow in hydrocarbon reservoirs: Geological Society Special Publication 147, p. 283-298.

Peterson, V.E., 1954, The Mounds and Farnham area of the northern San Rafael Swell, Carbon and Emery counties, Utah: Intermountain Association of Petroleum Geologists 5th Annual Field Conference, p. 86-88.

Pittman, E. D., 1981, Effect of fault-related granulation on porosity and permeability of quartz sandstones, Simpson Group (Ordovician) Oklahoma: AAPG Bulletin, v. 65, p. 2381-2387.

Santarelli, F. J., D. Dahen, H. Baroudi, and K. B. Sliman, 1992, Mechanisms of borehole instability in heavily fractured rock media: International Journal of Rock Mechanics, Mining Science and Geomechanical Abstracts, v. 29, p. 457-467.

Schulz, S. E., and J. P. Evans, 2000, Meoscopic structure of the Punchbowl fault, southern California, and the geologic and geo- 
physical structure of active strike-slip faults: Journal of Structural Geology, v. 22, p. 913-930.

Shipton, Z. K., 1999, Fault displacement profiles and off-fault deformation: interpreting the records of fault growth at the Chimney Rock fault array, Utah, USA: Ph.D. thesis, Edinburgh University, Edinburgh, United Kingdom, 251 p.

Shipton, Z. K., and P. A. Cowie, 2001, Damage zone and slip-surface evolution over $\mu \mathrm{m}$ to $\mathrm{km}$ scales in high-porosity Navajo Sandstone, Utah: Journal of Structural Geology, v. 23, no. 12. p. 1825-1844.

Terzaghi, K., 1965, Sources of error in joint surveys: Geotechnique, v. 15, p. $287-293$.

Thomas, K., Z. K. Shipton, and J. P. Evans, 2000, Stratigraphic and structural heterogeneities in faulted aeolian sandstone from borehole geophysics and cores, San Rafael Swell, central Utah (abs.): Geological Society of America Abstracts with Programs, v. 32, no. 7, p. A411.

Walsh, J. J., J. Watterson, A. E. Heath, and C. E. Childs, 1998, Representation and scaling of faults in fluid flow models: Petroleum Geoscience, v. 4, p. 241-251.

Welbon, A. I., A. Beach, P. J. Brockbank, O. Field, S. D. Knott, T. Pedersen, and S. Thomas, 1997, Fault seal analysis in hydrocarbon exploration and appraisal: examples from offshore midNorway, in P. Moeller-Pederson and A. G. Koestler, eds., Hydrocarbon seals, importance for exploration and production: Norsk Petroleum Society Special Publication 7, p. 125-138. 